NBER WORKING PAPER SERIES

\title{
THE IMPACT OF DISABILITY BENEFITS ON LABOR SUPPLY: EVIDENCE FROM THE VA'S DISABILITY COMPENSATION PROGRAM
}

\author{
David H. Autor \\ Mark Duggan \\ Kyle Greenberg \\ David S. Lyle \\ Working Paper 21144 \\ http://www.nber.org/papers/w21144 \\ NATIONAL BUREAU OF ECONOMIC RESEARCH \\ 1050 Massachusetts Avenue \\ Cambridge, MA 02138 \\ May 2015
}

This research was supported by the U.S. Social Security Administration through grant \#10-P-98363-1-05 to the National Bureau of Economic Research as part of the SSA Retirement Research Consortium. The views and findings expressed herein are those of the authors and do not purport to reflect the position of the U.S. Military Academy, the Department of the Army, the Department of Defense, the SSA, or the NBER. We are grateful to Josh Angrist, Orley Ashenfelter, Mary Daly, and seminar participants at Arizona State University, the Federal Reserve Board, Princeton University, and Stanford University for helpful comments. We are indebted to Luke Gallagher of the Army Office of Economic Manpower Analysis for outstanding research assistance and to Mike Risha of the Social Security Administration for assistance with all aspects of data development and interpretation. The views expressed herein are those of the authors and do not necessarily reflect the views of the National Bureau of Economic Research.

NBER working papers are circulated for discussion and comment purposes. They have not been peerreviewed or been subject to the review by the NBER Board of Directors that accompanies official NBER publications.

(C) 2015 by David H. Autor, Mark Duggan, Kyle Greenberg, and David S. Lyle. All rights reserved. Short sections of text, not to exceed two paragraphs, may be quoted without explicit permission provided that full credit, including $(\odot)$ notice, is given to the source. 
The Impact of Disability Benefits on Labor Supply: Evidence from the VA's Disability Compensation Program

David H. Autor, Mark Duggan, Kyle Greenberg, and David S. Lyle

NBER Working Paper No. 21144

May 2015

JEL No. J22

\begin{abstract}
Combining administrative data from the U.S. Army, Department of Veterans Affairs (VA) and the U.S. Social Security Administration, we analyze the effect of the VA's Disability Compensation (DC) program on veterans' labor force participation and earnings. The largely unstudied Disability Compensation program currently provides income and health insurance to almost four million veterans of military service who suffer service-connected disabilities. We study a unique policy change, the 2001 Agent Orange decision, which expanded DC eligibility for Vietnam veterans who had served in-theatre to a broader set of conditions such as type 2 diabetes. Exploiting the fact that the Agent Orange policy excluded Vietnam era veterans who did not serve in-theatre, we assess the causal effects of DC eligibility by contrasting the outcomes of these two Vietnam-era veteran groups. The Agent Orange policy catalyzed a sharp increase in DC enrollment among veterans who served in-theatre, raising the share receiving benefits by five percentage points over five years. Disability ratings and payments rose rapidly among those newly enrolled, with average annual non-taxed federal transfer payments increasing to $\$ 17 \mathrm{~K}$ within five years. We estimate that benefits receipt reduced labor force participation by 18 percentage points among veterans enrolled due to the policy, though measured income net of transfer benefits rose on average. Consistent with the relatively advanced age and diminished health of Vietnam era veterans in this period, we estimate labor force participation elasticities that are somewhat higher than among the general population.
\end{abstract}

David H. Autor

Department of Economics, E17-216

MIT

77 Massachusetts Avenue

Cambridge, MA 02139

and NBER

dautor@mit.edu

Mark Duggan

Stanford University

Department of Economics

579 Serra Mall

Stanford, CA 94305-6072

and NBER

mgduggan@stanford.edu
Kyle Greenberg

MIT Department of Economics

77 Massachusetts Ave

Cambridge, MA 02139

kgreenb@mit.edu

David S. Lyle

United States Military Academy

607 Cullum Road

West Point, NY 10996

David.Lyle@usma.edu 


\section{Introduction}

This paper investigates the effect of the U.S. Department of Veterans Affairs' (VA's) Disability Compensation (DC) program on the labor supply of military veterans. Since the ratification of the U.S. Constitution in 1789 , the federal government has provided cash benefits to disabled veterans. During the Civil War, the benefit was revised from a flat payment scheme to a graduated schedule based on disability severity. Multiple governmental agencies administered Veterans' benefits until the summer of 1930, when they were consolidated under a new federal agency called the Veterans' Administration. ${ }^{1}$

We focus on a major legislative change that took effect in 2001, which generated a plausibly exogenous increase in the generosity of disability benefits for one group of Vietnam Era veterans but not another. ${ }^{2}$ Motivated by an Institute of Medicine study that linked exposure to Agent Orange and other herbicides used by the U.S. military during the Vietnam War to the onset of type 2 diabetes, the VA in July of 2001 expanded the medical eligibility criteria for Vietnam veterans to include diabetes as a covered condition. This coverage expansion applied to veterans who served "in-theatre" in Vietnam, Cambodia, or Laos during the 1964 to 1975 period. It did not, however, apply to the approximately 55 percent of Vietnam era veterans who did not serve in theatre during the war.

The 2001 policy change coincided with a sharp acceleration in the number of veterans receiving DC benefits, documented in Figure 1. Some of this overall increase was attributable to a much higher rate of DC enrollment among veterans serving in the 1990s and 2000s than among their counterparts from earlier service eras. ${ }^{3}$ But much of it was driven by the rise in DC enrollment among Vietnam era veterans. As shown in Figure 2, the fraction of Vietnam era veterans receiving DC benefits had been trending up

\footnotetext{
${ }^{1}$ This was changed to the Department of Veterans Affairs in 1989.

${ }^{2}$ See Gruber (2000) for an analysis of a reform to the federal government's disability program in all parts of Canada except for Quebec that is estimated to have reduced labor supply.

${ }^{3}$ Veterans from the Gulf War and Global War on Terror are 2-3 times more likely than veterans from WWII or the Korean War era to receive DC benefits. Shifts in the composition of veterans (as those from older eras die and the recent era join the ranks) have contributed to a substantial increase in total DC enrollment.
} 
gradually prior to the 2001 policy change so that 9 percent of Vietnam-era veterans received DC benefits in that year. But there was a significant break in that trend after 2001 so that by 2013 more than 17 percent of Vietnam era veterans were receiving DC benefits. No similar changes in rates of DC enrollment occurred for veterans from earlier service eras. ${ }^{4}$

The policy-induced increase in DC enrollment provides an unusual opportunity to study how disability benefits affect the labor supply of near elderly male veterans. Adopting the terminology used by the military, we distinguish among 'boots on the ground' (BOG) Vietnam era veterans - the veterans directly affected by the Agent Orange policy—with 'not on ground' (NOG) veterans, whose DC benefit eligibility was not expanded. We analyze unique administrative data for a sample of more than 4 million U.S. Army veterans to compare the evolution of labor market outcomes among BOG veterans to other Vietnam era veterans who did not serve in the Vietnam theatre during the conflict there. By using other Vietnam era veterans as our comparison group, we account for the possibility that veterans would have retired sooner (or later) than non-veterans for reasons unrelated to the DC program. And given the large number of years of pre-2001 data included in our research data, we can control for possible differential trends between BOG and NOG veterans.

A large body of research investigates the effects of U.S. federal disability programs on health, employment, poverty, consumption and welfare. ${ }^{5}$ This research has focused almost exclusively on the Social Security Disability Insurance (SSDI) program, with early studies considering the effects on labor force participation (Parsons, 1980; Bound, 1989; Bound and Waidmann, 1992) and subsequent studies exploring the sensitivity of the program to economic conditions (Black et al, 2002) and the labor market effects of changes in the program's medical eligibility criteria and in effective replacement rates (Autor and Duggan, 2003). ${ }^{6}$ One challenge for this research is that, because SSDI is a federal program, there is

\footnotetext{
${ }^{4}$ See Duggan, Rosenheck, and Singleton (2010) for a comparison to veterans from earlier service eras.

${ }^{5}$ See for example the Handbook chapter by Bound and Burkhauser (1999).

${ }^{6}$ The labor supply consequences of the federal Supplemental Security Income (SSI) program are rarely studied because SSI largely serves individuals with extremely limited prior work histories (those with significant work histories normally qualify for SSDI).
} 
no natural comparison group against which to estimate the effects of the program. To address this issue, more recent research has estimated the effect of SSDI on the labor supply of applicants and beneficiaries by using variation in the propensity to award disability benefits across disability examiners (Maestas et al, 2013; Autor et al., 2014) and administrative law judges (French and Song, 2014). The findings from these studies, which utilize large-scale administrative data sets on both SSDI enrollment and earnings, suggest that labor force participation among marginal applicants - that is, those who would receive an SSDI award from a lenient judge or examiner but not from a stricter one-declines by about thirty percentage points as a result of receiving an SSDI award. ${ }^{7}$

There has been much less research on the VA's Disability Compensation program. Autor and Duggan (2007), Autor et al (2011), and Coile et al (2015) use data from the Current Population Survey (CPS) to explore how labor force participation changed for male Vietnam-era veterans relative to similarly aged non-veteran males after the 2001 policy change. All three studies demonstrate a significantly larger decline in labor force participation among Vietnam-era veterans in the post-2001 period, though their confidence intervals are compatible with a wide range of effect sizes. A concern with this body of work is that veterans might retire sooner than non-veterans for reasons unrelated to the DC program. ${ }^{8}$ Using the Vietnam-era draft lottery as an instrumental variable for Vietnam-era military service, Angrist et al (2010) estimate that employment was lower and transfer income receipt was higher among low skilled veterans than among low-skilled non-veterans. They hypothesize that the lower employment rate of Vietnam-era veterans is due to the availability of Veterans Disability Compensation benefits. In related work on the labor supply of veterans, Boyle and Lahey (2010) study the expansion of the Veterans Health Insurance

\footnotetext{
${ }^{7}$ Using an approach similar to Bound (1989), Chen and van der Klauuw (2008) estimate even smaller effects of SSDI enrollment, with an upper bound of a 20 percent reduction in labor force participation. Results from Von Wachter et al (2011) suggest labor supply effects may be larger for younger SSDI recipients. While SSDI reduces the incentive to work among recipients, the results of a recent policy change in Norway suggest that disability insurance recipients are responsive to changes in the magnitude of this incentive (Kostøl and Mogstad, 2014).

${ }^{8}$ Duggan et al (2010) use five years of data (odd-numbered years between 1997 and 2005) from the Veterans' Supplement to the CPS to compare changes in labor force participation among Vietnam veterans who served in theatre and other Vietnam era veterans. Given the small sample size, their estimates are very imprecise, as their confidence interval includes the full range of possible effect sizes (zero effect or a one-for-one reduction in labor force participation).
} 
program to non-disabled veterans in the mid-1990s to analyze changes in labor force participation stemming from increased real incomes and reductions in "job lock."

Using individual-level data from the U.S. Department of Veterans Affairs, we document that DC receipt and enrollment growth were higher among BOG than NOG veterans prior to 2001, but these gaps were relatively stable. After 2001, however, the rate of DC enrollment grew much more rapidly among BOG veterans, as shown in Figure 3. Between 2000 and 2006, the ratio of DC receipt among BOG relative to NOG veterans rose from approximately two-to-one to three-to-one: almost one-in-four BOG veterans in our analysis sample received DC benefits in 2006 versus one-in-twelve among veterans in our NOG sample. This trend break was driven primarily by a sharp increase in the number of diabetes awards to BOG veterans as shown in Figure 4. DC enrollment growth among BOG veterans shows essentially no break in trend when one excludes DC recipients with a diabetes diagnosis (Figure 5). Using matched data from the Social Security Administration, we also document a differential increase in SSDI enrollment after 2001 among BOG veterans. A plausible channel for this effect, which is about one-tenth as large as the corresponding change in DC enrollment, is that receipt of veterans disability benefits eases financial constraints associated with exiting the labor force and applying for SSDI benefits. Moreover, since SSA regulations require disability adjudicators to consider disability decisions of other federal agencies (U.S. General Accounting Office, 2009), a veteran's enrollment in DC may also increase the likelihood that he or she applies for and ultimately receives Social Security disability benefits.

By generating a sharp differential increase in DC enrollment among BOG veterans for reasons unrelated to changing health, the Agent Orange policy change permits causal estimation of the effect of DC program participation on the labor supply of near-elderly Vietnam veterans. Analyzing this policyinduced variation, we find that labor force participation, defined as having strictly positive earnings for the year in our administrative data, declined sharply among BOG relative to NOG veterans soon after the 2001 policy change. The results are similar for younger (born 1949-51) and older (born 1946-48) Vietnam veterans in our analysis sample, suggesting that this pattern reflects an effect of the policy rather than a tendency of BOG veterans to retire sooner than their NOG counterparts for reasons unrelated to the DC 
program. For every 100 individuals who entered the DC program as a result of the policy change, we estimate that 18 drop out of the labor force. The magnitude of this decline reflects in part the size of the cash transfers that DC beneficiaries receive. Among veterans who entered the DC program after 2001, annual benefits averaged $\$ 10 \mathrm{~K}$ in the first year of enrollment and $\$ 17 \mathrm{~K}$ in the fifth year of enrollment. Since DC benefits are not subject to state or federal taxation, their after tax value is 30 to 40 percent greater than nominally equivalent labor income. Indeed, the increase in disability benefit income among BOG veterans more than offset (on average) their reduction in earnings among BOG veterans, so that total incomes of BOG relative to NOG veterans rose steadily after 2001.

Combining our labor force participation and benefit receipt estimates, we obtain a non-participation elasticity of 0.50 . This estimate is larger than the figure of 0.16 reported by Coile and Gruber (2007) for the elasticity of retirement of near-elderly adults with respect to Social Security and other retirement wealth. ${ }^{9}$ Our estimates are highly consistent with the participation elasticities calculated by Boyle and Lahey (2010), however, who studied labor supply of older non-disabled veterans ages 55 through 64 who were granted access to VA health insurance in the mid-1990s.

Distinct from the SSDI program, which provides income replacement for beneficiaries who are unable to work due to disability, DC benefits are awarded as compensation for service-related reductions in health and thus, for the most part, are not contingent on veterans' past or present employment. This observation would suggest that any DC-induced reduction in labor supply that we detect would be attributable to a non-incentive income effect. However, nearly 14 percent of BOG veterans who were receiving DC by the end of our sample window were receiving maximum DC benefits of approximately $\$ 2,900$ monthly because they were deemed unable to work ('Individually Unemployable' or IU) due to their disability. For veterans receiving the IU benefit and those seeking it, the labor supply effects that we estimate are likely to encompass both income and incentive effects.

\footnotetext{
${ }^{9}$ A venerable literature estimates labor supply elasticites, including Frisch (1959), Ashenfelter and Heckman (1974), Abbott and Ashenfelter (1976), and Chetty (2012) among many key contributions. Very few studies estimate income elasticites of participation, however. McClelland and Mok (2012) provide a recent review.
} 
The labor supply effects that we document acquire added significance in light of the rapid growth in Disability Compensation enrollment, with annual benefit payments of $\$ 49.2$ billion in 2013 (U.S. Veterans Benefits Administration, 2014). Today’s veterans are substantially more likely than U.S. veterans of earlier cohorts to obtain DC benefits; indeed, veterans who have exited military service since 2001 are more than three times as likely as were Vietnam era veterans to receive disability compensation benefits soon after the completion of service. This cross-cohort contrast suggests that Veterans Disability Compensation program costs may rise substantially beyond what would be predicted based on earlier generations of veterans, a concern highlighted by Bilmes and Stiglitz (2008).

The analysis proceeds as follows. Section I discusses the financial and labor force participation incentives created by the Veterans Disability Compensation program. Section II describes the 2001 Agent Orange decision that made type 2 diabetes a service-connected disability for veterans who served in the Vietnam theatre. Section III details the construction of our data, which we use in Section IV to analyze the impact of the Agent Orange decision on veterans' enrollment in DC and their receipt of transfer income from DC and two other federal disability programs, SSDI and Supplemental Security Income (SSI). Section V presents reduced form estimates of the impact of the Agent Orange policy on labor force participation and total labor earnings. Section VI combines these margins to provide instrumental variables estimates of the impact of DC enrollment and total disability benefits payments on labor force participation. Section VII documents the effect of the Agent Orange policy on total measured income inclusive of disability benefits and net of any induced change in labor supply. Section VIII concludes.

\section{The Veterans Disability Compensation Program: Eligibility, Benefits and Work Incentives}

The DC program pays cash benefits and provides prioritized access to VA health facilities to military veterans with service-connected medical conditions, meaning that they are caused or aggravated by their military service. Unlike SSDI and SSI, federal programs that classify disability using a categorical (all-ornothing) determination, the DC program rates disability on a discrete scale with eleven gradations ranging from zero to 100 percent in ten percent increments. Ratings depend on the type and severity of the 
disability, with more severe conditions receiving a higher rating. ${ }^{10}$ If the recipient receives ratings for multiple disabilities, the recipient's Combined Disability Rating (CDR) is an increasing, concave function of the individual ratings, where concavity prevents the combined rating from exceeding 100 percent. $^{11}$

\section{A. Eligibility and benefits}

Veterans seeking DC benefits apply to one of 56 regional offices of the Veterans Benefit Administration (VBA), which collects necessary information and forwards the information to a Rating Board. For each disability claimed, the Rating Board determines whether the disability is verified, whether it is service connected, and if so, what rating it merits. During the 2000 fiscal year, more than 70 percent of those applying for DC sought benefits for more than one medical condition (U.S. Veterans Benefits Administration, 2001). Applicants face one of three possible outcomes: outright rejection, an award for some but not all conditions, or an award for all conditions. In 2006, current DC beneficiaries averaged 2.97 disabilities per recipient, with the highest number of disabilities per capita among Gulf War and Vietnam Era veterans, and the lowest number among WWII veterans (U.S. Veterans Benefits Administration, 2007).

Monthly benefits awarded by DC are an increasing and convex function of the veteran's CDR. In 2014, a 10 percent award provided a monthly payment of $\$ 131$ whereas a 100 percent award provided a monthly payment of $\$ 2,858 .{ }^{12}$ Veterans receiving a CDR of 30 percent or higher and who have spouses,

\footnotetext{
${ }^{10}$ The range of possible ratings differs among disabilities. For example, type 2 diabetes can have a rating of 10, 20, 40,60 , or 100 percent. Arthritis can be assigned a rating of 10 or 20 percent. For a list of conditions and ratings see http://www.warms.vba.va.gov/bookc.html. A disability with a 0 percent rating would not increase the monthly cash benefit but would entitle the veteran to priority for health care through the Veterans Health Administration.

${ }^{11}$ If a claimant has multiple disabilities, only the claimant's 'residual ability' is considered when determining the effect of each additional disability on the CDR. For example, if a veteran has two disabilities rated at $50 \%$, his CDR would be he equal to the sum of $50 \%$ for the first disability and $50 \%$ of his residual capacity of $50 \%$ for the second disability, all rounded to the nearest increment of $10 \%$. Thus, two disabilities rated at $50 \%$ results in a CDR of [0.5+ $(1-0.5) * 0.5]=0.75$, which is then rounded up to 0.80 .

${ }^{12}$ The stated policy of the VBA that the DC benefits schedule reflects the average reduction in earnings capacity for each value of the CDR. Since benefits determination depends only on CDR and family status, it is clear that the benefit payment will exceed the earnings loss for some veterans and fail to meet the earnings loss of others. In 2014, the monthly benefit schedule (by CDR) was: $\$ 131(10 \%), \$ 259(20 \%), \$ 401(30 \%), \$ 578(40 \%), \$ 822(50 \%)$, $\$ 1,041(60 \%), \$ 1,312(70 \%), \$ 1,526(80 \%), \$ 1,714(90 \%)$, and $\$ 2,858(100 \%)$.
} 
dependent children, or surviving parents also receive modest additional benefits. The VBA also considers employment capability for veterans with severe disabilities. Veterans who have single disabilities rated at 60 percent or above or a combined disability rating of at least 70 and one disability rated at least 40 can qualify for the Individual Unemployability (IU) designation if VBA determines that they are unable to "to secure and follow a substantially gainful occupation by reason of service-connected disability." Veterans receiving the IU designation are provided cash payments at the 100 percent CDR level even if their CDR is less than 100 percent.

Veterans Disability Compensation benefits typically have longer award durations and fewer work restrictions than other federal disability benefits. DC benefits are also not subject to federal income or payroll tax; hence, a dollar in DC income is roughly equivalent to $\$ 1.30$ to $\$ 1.50$ in pre-tax earned income, depending upon the recipient's marginal tax rate. DC benefits generally do not offset and are not offset by other federal transfer benefits, and, once awarded, are rarely retracted. ${ }^{13}$ Unlike federal SSDI benefits, DC benefits do not terminate when a recipient reaches retirement age, even for recipients receiving the IU benefit. Moreover, a veteran's ongoing receipt of DC benefits is neither work-contingent nor income-contingent, except for veterans who have received the IU rating. ${ }^{14}$ Thus, DC benefits are roughly akin to an inflation-indexed annuity that provides monthly payments for as long as a veteran remains alive.

Appendix Table 1 summarizes DC cash benefits paid in fiscal year 2006, the final year for which we have individual-level DC data in the analyses below. The first three columns enumerate the count of recipients, the total dollars paid, and the average annual benefit in each CDR category at the end of fiscal year 2006. The average annual payment to the 2.73 million DC recipients in this year was $\$ 10,862$ per

\footnotetext{
${ }^{13}$ A Veteran may receive both DC and SSDI payments without any reduction in benefits from either program, though SSI payments will generally be reduced or eliminated by DC payments.

${ }^{14}$ A veteran can lose the IU rating if his annual labor market earnings (measured by SSA earnings data) exceeds a threshold amount, which was equal to \$6,000 in 2004 and 2005. The General Accounting Office notes, however, that "this process relies on old data, outdated and time-consuming procedures, insufficient guidance, and weak eligibility criteria” (GAO 2006, p. 23).
} 
capita, totaling approximately $\$ 29.6$ billion for the year. Veterans with ratings between 0 and 20 percent accounted for 44 percent of recipients but just 8 percent of dollars paid. Those with ratings at 70 percent or above comprised 21 percent of the population and received 62 percent of the benefits payments. ${ }^{15}$

Total DC benefits payments rose from $\$ 20.8$ billion to $\$ 49.1$ billion between 2001 and 2013 (in constant 2013 dollars). Simultaneously, the estimated veteran population declined from 26.1 million to 22.1 million (VBA, 2002 and 2014). As a result of these changes, real annual DC expenditures per living veteran increased by 180 percent (from $\$ 798$ to $\$ 2,234$ ).

\section{B. Work Incentives under DC}

The graduated scale of DC disability ratings creates a complex set of incentives. Though disability ratings for DC recipients notionally depend exclusively on medical criteria rather than employment status, veterans may nevertheless perceive that their disabilities will receive higher ratings if they are not employed when applying to obtain or increase benefits. Veterans also face an incentive to repeatedly reapply to increase their Combined Disability Ratings - and therefore their benefits - as their health conditions evolve. ${ }^{16}$ One consequence is that veterans' CDRs and benefit levels tend to rise steeply in the years following enrollment, as shown in panels $\mathrm{A}$ and $\mathrm{B}$ of Table $1 .{ }^{17}$ This pattern of rapidly escalating benefits following enrollment suggests that policies that induce veterans to obtain an initial DC award, even at a low CDR, may lead to substantially larger claims over the longer term and discourage labor force participation.

The availability of the Individual IU designation is likely to amplify these incentives. The IU benefit has significant monetary value: a 2006 General Accounting Office report found that the average present

\footnotetext{
${ }^{15}$ The average monthly benefit amounts for those with ratings between 0 and 20 percent are very close to the baseline amounts because veterans with these ratings are not eligible for dependent benefits. The average amounts paid for those rated 60 percent and higher are substantially greater than the baseline amounts because many of these recipients are eligible for the 100 percent payment amount because they are receiving the IU benefit.

${ }^{16}$ In fact, we observe very few reductions in CDRs in our data, and it is possible that those few that exist reflect coding errors. Veterans face little risk of having their CDRs reduced after the initial award.

${ }^{17}$ We describe the sample used to construct Table 1 in Section III below. Although our data codes DC receipt in each year from 1998 through 2006, we can only determine what year DC was awarded if a veteran is observed not receiving DC in a prior year. We can thus identify DC enrollment cohorts from 1999 forward, but not for 1998.
} 
discounted incremental value of receiving an IU award in 2005 was approximately $\$ 300$ to $\$ 460$ thousand for veterans age 20 (net of existing benefits), and was $\$ 89$ to $\$ 142$ thousand for veterans age 75 (U.S. GAO, 2006). ${ }^{18}$ The availability of this benefit appears likely to induce at least some subset of workcapable veterans to curtail labor force participation to qualify. Once the IU designation is awarded, veterans face an incentive to maintain low earnings since the benefit is technically only available for those with labor market earnings at or below the poverty level for a single individual (U.S. GAO, 2006). ${ }^{19}$

The DC program may also alter work incentives through its interactions with other federal benefits programs, SSDI in particular. Though the DC and SSDI programs have distinct disability screening criteria, the medical information generated by the DC award may alert some veterans that they suffer from impairments that could merit an SSDI award (and vice versa). Receipt of DC benefits may also render the SSDI application process less financially onerous, since SSDI applicants must remain out of the labor force for at least five months before receiving SSDI benefits. Because cash benefits from the two programs are additive rather than offsetting, it is plausible that a veteran's receipt of either DC or SSDI benefits increases his odds of applying for the other. ${ }^{20}$

\section{The 2001 Agent Orange Decision, Type 2 Diabetes and 'Service-Connectedness'}

For a disability to be classified as service-connected, it must be "a result of disease or injury incurred or aggravated during active military service." This criterion makes it straightforward for a veteran to obtain compensation for a tangible injury that occurs during military service but significantly more

\footnotetext{
${ }^{18}$ Among veterans in our sample who received benefits at the 100 percent disability level in 2006, about half were designated as IU. We henceforth do not distinguish between the IU benefit and 100 percent disability since many DC recipients with 100 percent disability may have previously qualified for the IU benefit with a lower CDR.

${ }^{19}$ The fact that only veterans with severe disabilities (a CDR of 60 or higher) are eligible for the IU benefit might be expected to deter all but the most disabled veterans. But the data in Table 1 indicate that very high CDRs are not uncommon, even for veterans that initially enter with low or moderate CDRs. Among veterans awarded DC benefits in 1999, only 15 percent qualified for either the IU benefit or 100 percent disability (panel C). Seven years later, in 2006, three times that number (45 percent) of the 1999 DC enrollment cohort was either receiving the IU benefit or was 100 percent disabled.

${ }^{20}$ The combination of VA health benefits and Medicare benefits from SSDI may also be more attractive than either individually since VA and Medicare differ in ailments covered, rapidity of access to treatment, size of co-pays, and coverage of prescription drugs.
} 
difficult to obtain compensation for a disease that develops later in life, such as cancer or heart disease. Thus in 2006, the five most prevalent service-connected disabilities were primarily battle traumas: hearing defects, tinnitus, general musculoskeletal disorders, arthritis due to trauma, and scars (U.S. Veterans Benefits Administration, 2006). Nevertheless, disabilities that typically develop post-service are also prevalent: post-traumatic stress disorder (PTSD) and hypertensive vascular disease (high blood pressure) were the sixth and ninth most prevalent service-connected disabilities in 2006.

In November of 2000, type 2 diabetes was added to the list of compensable and presumptively service-connected impairments for Vietnam veterans who had served in theatre due to their potential exposure to the herbicide Agent Orange. This policy change substantially weakened the link between service-connectedness and DC benefits for eligible veterans. The Agent Orange policy was years in the making. The U.S. military applied more than 19 million gallons of herbicides to defoliate Vietnamese jungle areas between 1962 and 1971, a quantity of defoliant sufficient to cover 8.5 percent of the country's land area (U.S. Department of Veterans Affairs, 2003). ${ }^{21}$ After the war ended, concern grew among veterans that their exposure to the dioxins in Agent Orange would have long-term adverse consequences. The VA responded by establishing the Agent Orange Registry in 1978. In 1991, Congress enacted the Agent Orange Act, which charged the National Academy of Sciences' Institute of Medicine (IOM) with reviewing the evidence for a link between Agent Orange exposure and the prevalence of certain medical conditions.

In a series of reports, the IOM found insufficient evidence to establish an association between dioxin exposure and diabetes. But the publication of two new studies in 1999 and 2000 that found an association between dioxin exposure and diabetes turned the tide against this longstanding consensus (Calvert et. al., 1999; Air Force Health Study, 2000). In October of 2000, the IOM concluded that there was "limited/suggestive evidence of an association between exposure to the herbicides used in Vietnam or the

\footnotetext{
${ }^{21}$ Agent Orange accounted for more than 80 percent of the total amount of herbicide dispensed.
} 
contaminant dioxin and type 2 diabetes" (IOM, 2000). ${ }^{22}$ This in turn prompted the Secretary of Veterans Affairs' decision to classify type 2 diabetes as presumptively service connected.

The VA's adoption of the Agent Orange policy offers an unusual opportunity: almost three decades after the end of the Vietnam War, veterans who served in theatre were unexpectedly granted presumptive eligibility for financially significant Disability Compensation benefits without a precipitating change in health. This paper exploits the contrast in expanded benefits eligibility between in-theatre and not-intheatre veterans - whom we refer to as 'boots on ground' (BOG) and 'not on ground' (NOG) veteransto study the impact of benefits receipt on veterans' labor supply.

\section{Data and Analytic Sample}

Our research draws on a unique set of linked administrative data sources. The first is a near census of approximately four million veterans who left the Army between 1968 and 1985. The U.S. Army's Office of Economic and Manpower Analysis (OEMA) constructed this database by combining two files from the Defense Manpower Data Center (DMDC): the first DMDC file enumerates essentially every person who left the Army between 1968 and 1985 (designated as the service member's "loss year"); OEMA then merged this "loss year" file with DMDC's Vietnam file, which identifies the vast majority of veterans who served in the Vietnam theatre. ${ }^{23}$ Approximately 36 percent of this sample served with boots on the ground in Vietnam, Cambodia, or Laos during the Vietnam War era, and is therefore potentially directly affected by the 2001 expansion of the DC program's medical eligibility criteria. More than 35 percent of the NOG sample had a start year of 1976 or later and thus did not serve during the Vietnam War era. ${ }^{24}$

\footnotetext{
${ }^{22}$ The same 2000 report by the National Academy of Sciences' Institute of Medicine explained that any increased risk of Type 2 diabetes due to Agent Orange appeared to be small and that family history, physical inactivity, and obesity were far greater predictors of diabetes (IOM, 2000).

${ }^{23}$ The file does not include the comparatively small number of Army service members who died during service. U.S. government archives record 38,224 Army service members who were killed in action in Vietnam.

${ }^{24}$ Veterans who were in the "loss year" file and the Vietnam file are in the BOG sample while veterans who were in the "loss year" file but not the Vietnam file are part of the NOG sample. The Vietnam file contained loss year information for approximately 25 percent of veterans, which explains why a small fraction of the BOG sample has a loss year before 1968 or after 1985. Our final analysis sample, described below, excludes all veterans with loss years before 1968 or after 1985, but does contain a few veterans who were in the Vietnam file but not in the "loss year"
} 
Appendix Table 2 and Table 2 show summary statistics on the distribution of loss years, years-of-birth, and start years for military service.

We use three additional data sources to measure mortality, employment, and disability outcomes for Vietnam era veterans. To measure DC participation, OEMA obtained from VA detailed information about veterans' enrollment and DC benefits received from VA programs in September of each year from 1998 through 2006. To account for mortality, OEMA merged their data to the Social Security Administration Death Master File (DMF), which includes the year of death for any individual in the sample who died prior to 2008. According to DMF data, approximately 13 percent of the 4.1 million individuals in the sample were deceased by late 2007 .

To collect employment, earnings, SSDI, and SSI information, OEMA contracted with the U.S. Social Security Administration (SSA) to match veterans in the OEMA data set to enumerate wage earnings and Social Security benefits in each year from 1976 through $2007 .{ }^{25}$ This resulted in a successful match for 3.8 of the 4.1 million veterans in the full data set, with overall match rates exceeding 90 percent for both BOG and NOG samples, as detailed in Appendix Table 3.

Confidentiality rules prevent SSA from disclosing individual earnings or benefits data. SSA instead provided statistics on earnings and benefits for cells containing five to nine veterans. These statistics include the number of cell members with zero earnings, mean labor earnings, the number receiving SSDI and SSI, and mean SSDI and SSI benefit amounts. In constructing cells, we grouped individuals with similar background characteristics, including gender, race, BOG and NOG status, and year of birth. Our final analysis sample consists of veterans who joined the military between 1966 and 1971, and were born between 1946 and 1951 (see Table 2). See the data appendix for more details on the cell construction and sample selection.

Panel A of Table 3 compares the BOG and NOG samples. The fraction nonwhite is approximately

file. This group comprises only 1.25 percent of our final sample and our results are nearly identical when we exclude them from our analysis.

${ }^{25} \mathrm{SSA}$ required a match on social security number, last name, and date of birth of each individual to make a match. 
equal in the two samples (11.3 and 11.8 percent, respectively) as is the fraction with positive earnings in 1998 (84.4 and 85.1 percent). Among those with a non-missing Armed Forces Qualification Test score (AFQT), the average scores are also relatively close (52.1 and 53.4). And by construction, the average year-of-birth and the average start year are comparable in the two groups. There are clear differences between the BOG and NOG samples as well. BOG veterans are more than twice as likely as NOG veterans to be receiving DC benefits in 2000 ( 14.3 versus 6.5 percent), just prior to the 2001 policy change described above. This in part reflects the greater toll that military service took on those who served in the Vietnam theatre. ${ }^{26}$

An examination of trends in key outcome variables in the BOG and NOG samples prior to the 2001 policy change reveals many similarities: the fraction with zero earnings increased by similar, though not identical, amounts for both samples between 1998 to 2000 (by 1.5 and 1.0 points for BOG and NOG samples, respectively), as did the fraction receiving SSDI benefits (1.2 and 0.9 points for BOG and NOG samples). Our analysis will control for any differential trends in outcome variables that precede the policy change.

A remaining concern with the primary analytic sample is that individuals who are matched in the SSA data may systematically differ from those who are not. This is especially an issue for veterans who died prior to 1997. As shown in columns 3 and 4 of panel B in Table 3, the fraction of veterans in the full sample who were deceased as of 1997 was 6.2 and 6.1 percent in the full BOG and NOG samples but only 4.8 and 2.9 percent in the SSA verified samples - though, notably, the fraction of veterans who died between 1997 and 2007 in the BOG and NOG samples is closely comparable in both the full sample and the SSA verified sample. ${ }^{27}$ The lower SSA match rate for deceased veterans is a consequence of SSA's record matching criteria, which require a match on subjects' full names as well as SSN and date of birth.

\footnotetext{
${ }^{26}$ Additionally, members of the NOG sample are more likely to have missing data on education and less likely to be missing AFQT score data.

${ }^{27}$ We constructed the sample summarized in panel B of Table 3 in the same manner as the sample summarized in panel A, except that we did not exclude veterans who did not match with SSA earnings information.
} 
Due to poor optical character recognition, the NOG data contained a relatively high frequency of garbled names. We worked with the credit information provider TransUnion to obtain names for those with incomplete information. ${ }^{28}$ Due to limited availability of archival credit information prior to 1997 , TransUnion could not provide names for most veterans who passed away before that same year, leading to a low overall match rate for NOG soldiers who died prior to 1997 . Differential mortality match for the BOG and NOG samples is not a major threat to the validity of our research design, however, since our primary focus is on outcomes from 1998 forward. Thus, soldiers who were deceased as of 1997 are excluded from the analysis.

To benchmark the representativeness of the sample, we compare the OEMA data with a similarly drawn group of males from the 2000 IPUMS Census file. Using the 5 percent Census IPUMS extract, we draw a group of all males born between 1946 and 1951, and further limit the sample to (self-reported) Vietnam-era veterans. ${ }^{29}$ Appendix Table 4 provides a side-by-side comparison of age, race, schooling, annual earnings, and share with non-zero earnings in the OEMA and Census samples. Race and labor force participation rates are closely comparable: the fractions of the OEMA and Census samples with non-zero earnings are 84.1 percent and 82.2 percent, respectively, while the percent nonwhite are 11.3 and 13.3. Reflecting the fact that OEMA data code education at the time of military enlistment (average age of 20) while the Census data code educational attainment in late adulthood, the OEMA sample reports considerably lower educational attainment than the Census sample. Average earnings in the OEMA sample are also about 10 percent lower than in the Census sample. This gap may reflect earnings differences between Army veterans and those of other branches of the military. SSA data may also fail to capture some earnings sources, including self-employment and non-covered work. Overall, our

\footnotetext{
${ }^{28}$ TransUnion performed this work pro bono. Our original sample had 1.7 million observations with a missing name. TransUnion was able to provide names for 1.5 million of these observations upon confirming a match with date of birth and social security number.

${ }^{29}$ The Census data do not allow us to distinguish among veterans according to their branch of military service. To the extent that Army veterans are different from their counterparts serving in the Navy, Air Force, Marines, or Coast Guard, we would expect some differences between the Census and OEMA samples.
} 
comparison of OEMA and Census data provides some assurance that the OEMA sample is representative of the target population of Vietnam era Army veterans, measured in terms of age, race, labor force participation and earnings.

\section{The Impact of the Agent Orange Policy on Receipt of Disability Benefits}

The Agent Orange policy spurred a steep rise in Disability Compensation enrollment, and may potentially have had spillover effects on enrollment in other federal disability programs as well. We begin by estimating impacts on DC enrollment, followed by SSDI and SSI enrollment, and finally, total federal disability benefits.

\section{A. Enrollment in Veterans Disability Compensation}

Figure 3 plots the fraction of BOG and NOG veterans receiving DC benefits in September of each year from 1998 through 2006. Prior to the Agent Orange change in 2001, DC enrollment was rising somewhat more rapidly among BOG than NOG veterans. But DC enrollment among BOG veterans accelerated substantially after 2001. Column 2 of panel A in Table 4 shows that BOG DC enrollment increased by 0.4 percentage points per year between 1998 and 2000 (13.5 to 14.3) and by 1.6 percentage points annually between 2001 and 2006 (15.0 to 23.0). In contrast, DC enrollment growth rates among NOG veterans remained small and relatively steady, increasing from 0.1 percentage points per year between 1998 and 2000 (6.3 to 6.5) to 0.2 percentage points per year between 2001 and 2006 (6.6 to 7.6). ${ }^{30}$ Data from the National Health Interview Survey (Schiller et al, 2010) indicate that the fraction of individuals with diabetes varies substantially by race, with rates among blacks substantially higher than among whites. Consistent with this fact, an examination of the trends in DC enrollment in Table 4 reveals substantial differences by race in the BOG sample, with DC enrollment increasing about 40 percent more among BOG nonwhites (19.3 to 30.2, 10.9 percentage points) than among BOG whites from 2001 to

\footnotetext{
${ }^{30}$ The policy change took effect in July of 2001 and we measure DC enrollment in September. Thus, our 2001 data is arguably more "pre" than "post," though it's likely that the policy change did contribute to DC enrollment growth between September 2000 and September 2001 in our data.
} 
2006 (14.4 to $22.1,7.7$ percentage points).

These raw differences in DC enrollment trends between BOG and NOG veterans may reflect differences in veteran characteristics in addition to any impact of the Agent Orange policy. To account for these factors, we estimate a set of OLS models that regress DC enrollment on a full set of controls for veterans' year-of-birth, race, and AFQT score quintile. ${ }^{31}$ For consistency with the subsequent analysis of labor market outcomes, our DC variables are calculated as means over five to nine veterans grouped at the level of SSA reporting cells. ${ }^{32}$ We estimate the following equation for 1998 through 2006, weighting each cell-year by the number of individuals in the cell:

$$
Y_{j t}=\alpha_{t}+\gamma_{0} \times B O G_{j}+\sum_{1999}^{2006} \gamma_{t} \times B O G_{j}+X_{j t}^{\prime} \beta_{t}+\varepsilon_{j t}
$$

The outcome variable $Y_{j t}$ is the percentage of cell $j$ enrolled in the DC program in September of year $t$, and $B O G_{j}$ is an indicator variable that is set equal to one if veterans in cell $j$ are in the BOG sample and is otherwise equal to zero (cells include either all BOG or all NOG veterans). The term $\alpha_{t}$ is a vector of nine indicator variables for each year considered, and $X_{j t}$ is a vector set of 14 variables corresponding to the possible values of year-of-birth, AFQT quintile, and race. ${ }^{33}$ We interact each of these 14 indicator variables with nine year-specific indicator variables to account for differential levels of growth rates in DC enrollment by age, race, or AFQT level during the 1998 through 2006 period. The coefficient $\gamma_{0}$

\footnotetext{
${ }^{31}$ Veterans with low AFQT scores are more likely to enroll in DC (Autor et al 2011), and average scores differ slightly between BOG and NOG veterans.

${ }^{32}$ SSA outcomes are only available at the cell level due to confidentiality restrictions, as discussed above. Because we apply OLS models to cell means and weight by the number of individual observations in each cell, the cell level estimates will be in most cases algebraically identical to those that we would obtain if cells were instead disaggregated to individual level rows. The one exception to this dictum arises from the fact that ten percent of cells in have more than one AFQT quintile represented within the cell. We assign the cell to the AFQT quintile nearest to the cell's mean AFQT quintile in these cases, meaning that the cell-level and corresponding individual level regressions will differ slightly.

${ }^{33}$ In our sample there are six possible values of YOB (1946 through 1951), two possible values of race (white and nonwhite), and six possible values of AFQT quintiles (we group those with a missing AFQT into a sixth category). Given there are nine years of data used in these estimates, we are including 126 interactions. Veterans within each cell have the same year-of-birth and race (by construction) and the vast majority also have the same AFQT quintile. Data for each veteran is included in each of these nine years unless the veteran dies at some point between 1998 and 2006 , in which case the veteran is dropped from the sample. Year-of-death is one of the variables used to construct the cells, so typically the entire cell is dropped.
} 
corresponds to the (conditional) baseline DC enrollment gap between BOG and NOG veterans in the base year of 1998, while the coefficient vector $\gamma_{t}$ estimates the difference in this gap in each subsequent year 1999 through 2006 relative to the enrollment gap in 1998.

The statistically significant estimate of 6.97 for $\gamma_{0}$ in the first column of panel A, Table 5 implies a 7 percentage point gap in DC enrollment between the BOG and NOG samples in the baseline year (1998) after controlling for race, year-of-birth, and AFQT quintile, quite similar to the unconditional estimated difference of 7.2 percentage points in columns 1 and 2 of Table 4 (13.5 for BOG versus 6.3 for NOG). The next eight rows of the first column in Table 5 display the estimates for $\gamma_{t}$ in each year from 1999 through 2006. The statistically significant estimates of 0.33 and 0.59 for $\gamma_{1999}$ and $\gamma_{2000}$ imply that DC enrollment was increasing more rapidly (by 0.3 percentage points annually) for the BOG than NOG sample prior to the 2001 policy change. Beginning in 2001, these coefficients increase much more rapidly, by about 1.4 percentage points per year, and reach a cumulative differential of 7.98 percentage points by September of 2006. As shown in panels B and C of Table 5, the point estimates differ only modestly by birth cohort (1946-48 and 1949-51), with slightly larger effects for the older than the younger group (8.28 and 7.65 percentage points, respectively).

The sharp break in trend for DC enrollment among BOG relative to NOG veterans motivates a parameterized version of equation (1) found in even-numbered columns of Table 5. For this specification, we replace the full set of year-by-BOG interactions with two linear time trends: a pre-2001 trend and a post-2001 trend change, estimated relative to the pre-2001 trend:

(2) $Y_{j t}=\alpha_{t}+\gamma_{0} \times B O G_{j}+\delta_{0} \times B O G_{j} \times(t-1998)+\delta_{1} \times B O G_{j} \times(t-2001) \times 1[t \geq 2002]+X_{j t}^{\prime} \beta_{t}+\varepsilon_{j t}$ Here, $\delta_{0}$ captures the pre-existing trend in BOG relative to NOG DC participation just prior to the policy change while $\delta_{1}$ estimates any additional change in the BOG relative to the NOG trend following the policy. We define 2002 to be the first post-policy year in this specification given that most of the time from September 2000 to September 2001 occurred before the policy took effect in July 2001. To interpret $\delta_{1}$ as the causal effect of the Agent Orange policy change on DC enrollment, we must assume that the 
pre-existing trend in the difference in DC enrollment between the BOG and NOG samples would have continued after 2001.

The estimates in the even-numbered columns of Table 5 highlight the significant trend increase in DC enrollment among BOG relative to NOG veterans following the 2001 policy change. Because we treat 2001 as a pure pre-policy year, the estimate of $\delta_{0}$ in each case is slightly larger and the estimate of $\delta_{1}$ slightly smaller than is suggested by the year-by-year estimates. The magnitude of the trend break is similar between the two birth cohort groups (1946-48 and 1949-51). In panel A of Table 6, we split the sample by race (white/nonwhite) and by AFQT score. The acceleration in DC enrollment is largest among BOG veterans who are nonwhite and have relatively low (below the $40^{\text {th }}$ percentile in the sample) AFQT scores. $^{34}$

Figures 4 and 5 relate these enrollment trends to the Agent Orange policy. Figure 4 documents a steep increase in the likelihood that BOG (but not NOG) veterans receive compensation for diabetes, both in the year of current DC receipt and in the year of initial DC enrollment. As documented in Panel C of Table 4, the fraction of DC beneficiaries receiving compensation for diabetes among BOG veterans rose from 2.4 to 28.1 percent (25.7 points) between 2001 and 2006 versus 1.6 to 6.4 percent among NOG veterans (4.8 points). ${ }^{35}$ Yet, as shown in Figure 5, there was only a modest increase in the fraction of veterans receiving DC benefits absent a diabetes award. Thus, the rapid growth in DC enrollment appears substantially accounted for by an influx of new diabetes awards. Figure 6 underscores that the increase in DC enrollment was similarly rapid among older (YOB 1946-48) and younger (YOB 1949-51) Vietnam veterans in our sample, as indicated by the regression estimates in Table 5.

\footnotetext{
${ }^{34}$ We drop cells with missing AFQT scores for these specifications.

${ }^{35}$ There are three likely reasons that DC receipt for diabetes increased in the NOG. One is that our data only imperfectly classify BOG and NOG veterans; some veterans categorized as NOG may in fact have served in theatre and hence presumptively qualified for service-connectedness for their type 2 diabetes. A second cause is that administration of DC benefits appears to be somewhat discretionary. Even prior to the Agent Orange decision in 2000, 1.4 percent of BOG and 0.7 percent of NOG DC recipients were receiving compensation for serviceconnected diabetes (panel C of Table 4). Finally, some NOG veterans may have served in Korea in 1968 or 1969. This source of slippage does not invalidate our identification strategy provided that the post-2001 trend break in DC receipt in BOG versus NOG veterans is induced by the Agent Orange Policy change, which seems quite plausible.
} 
The estimates so far capture the extensive margin impact of the Agent Orange policy on DC participation. Panels B and C of Table 6 consider outcome measures that combine responses along the extensive (enrollment) and intensive (rated severity) margins: Combined Disability Ratings (CDRs) and annual benefits payments, both of which are continuous measures of DC participation. ${ }^{36}$ Both CDRs and annual benefit payments rose significantly more rapidly for BOG than NOG veterans after 2001. Panel B of Table 6 shows that prior to the Agent Orange policy, average CDRs of BOG relative to NOG veterans were rising at 0.34 percentage points annually; after 2001, this differential trend tripled to 1.00 percentage points annually $(0.34+0.66)$. Similarly, panel $\mathrm{C}$ indicates that the year-over-year increase in annual mean DC benefits paid to BOG relative to NOG veterans rose from $\$ 113$ prior to the policy change to $\$ 305$ per year after $2001(\$ 113+\$ 192)$. Consistent with the estimates for DC enrollment by race and AFQT score, the remaining columns of panels $\mathrm{B}$ and $\mathrm{C}$ demonstrate that $\mathrm{CDRs}$ and benefits payments increased more rapidly among nonwhite than white BOG veterans, and more rapidly among low-AFQT than high-AFQT BOG veterans.

\section{B. Enrollment in other Federal Disability Programs}

A significant constraint that some workers face when applying for SSDI benefits is that they are unlikely to qualify for an award if they participate gainfully in the labor force while their case is being decided (Autor et al., 2014). Knowledge of this fact may deter workers with residual work capacity from applying for benefits since they would have to forfeit potential earnings in pursuit of an uncertain benefit. Since, as we document below, many veterans did leave the labor force after becoming eligible for DC benefits, it is plausible that a subset that would otherwise have been deterred from seeking SSDI benefits would choose to pursue these benefits as an indirect consequence of the Agent Orange policy. ${ }^{37}$

\footnotetext{
${ }^{36}$ Veterans receiving the IU rating are coded with a CDR of 100 since they receive benefits at the 100 percent disability level.

${ }^{37}$ Borghans et al (2014) find related evidence of program spillovers in disability receipt. On average, Dutch DI recipients offset a $€ 1.00$ loss in DI benefits with a $€ 0.30$ increase in other social support programs. Duggan et al (2007) find evidence that reductions in Social Security retirement benefits stemming from the rising U.S. Full Retirement Age have lead to an increase in SSDI enrollment among cohorts facing a higher full retirement age.
} 
To examine these potential spillovers, we estimate models analogous to equation (2) where the outcome variable is the probability of SSDI receipt among BOG and NOG veterans (again measured at the level of SSA reporting cells). Reflecting the longer sample window available for the SSA outcomes, these models include two additional "pre" years, 1996 and 1997, and one additional "post" year, 2007. Panel A of Table 7 shows that, like DC enrollment, SSDI receipt was trending upward faster among BOG than NOG veterans by 0.13 percentage points per year prior to the 2001 policy change. But this trend accelerated after 2001 , increasing to 0.25 percentage points $(0.13+0.12)$ annually. Notably, the magnitude of the estimated effect on SSDI is only about 10 percent as large as the corresponding estimate for DC enrollment (compare column 1, panel A of Tables 5 and 6$){ }^{38}$ These results suggest that the Agent Orange policy likely spurred additional SSDI enrollment, which may in turn have magnified any reduction in labor force participation among eligible veterans.

In panel B of Table 7, we estimate models for receipt of SSI. Here, the estimates point in the opposite direction: SSI enrollment was growing more rapidly among NOG than among BOG veterans prior to 2001, and this trend accelerated after 2001, in all likelihood because the additional DC transfer income made some veterans ineligible for means-tested SSI benefits. The magnitude of the estimated break in trend for SSI is only one-tenth as large as the corresponding estimate for SSDI, however.

The final panel of Table 7 estimates equation (2) for disability income combining benefits payments from all three federal disability programs: DC, SSDI, and SSI. These estimates only include data from 1998 through 2006 since we do not have DC data for 1996, 1997, and 2007. Inclusion of SSDI and SSI benefits with DC benefits raises the differential trend increase in benefits payments for BOG relative to NOG veterans by approximately an additional 15 to 20 percent (compare to panel C of Table 6). Across all veterans in our sample, combined disability benefits were rising by $\$ 128$ annually among BOG relative to NOG veterans prior to the 2002 Agent Orange policy change. Commencing in 2002, this differential trend rose to $\$ 354(\$ 128+\$ 226)$. This average masks considerable heterogeneity. For

\footnotetext{
${ }^{38}$ In estimates not displayed, we find impacts on SSDI receipt that are similar for the 1946-48 and 1949-51 cohorts.
} 
veterans with high CDRs, DC benefits payments substantially exceed SSDI benefits for all but the highest (pre-disability) earners; moreover, DC benefits are not subject to federal taxation. Thus, the bulk of the impact of the Agent Orange policy on veterans' transfer income accrues through the DC program.

\section{Consequences for Labor Force Participation}

We now consider impacts of the Agent Orange policy on veterans' employment and earnings. Using models analogous (1) and (2), we test whether the fraction of BOG veterans in the labor force declined differentially relative to NOG veterans following the 2001 policy change. We again include data from 1996, 1997, and 2007 because of the longer sample window available for SSA outcomes.

\section{A. Impacts on labor force participation}

Table 8 considers the impact of the Agent Orange policy on labor force participation, measured as the percentage of living veterans in an SSA reporting cell who have positive labor earnings. The first column finds that labor force participation among BOG veterans in the baseline year of 1996 was slightly lower (by 0.32 points) among BOG than NOG veterans. This participation gap was modestly expanding (i.e., becoming more negative) in the early part of our sample period, falling by an additional 0.81 points between 1996 and 2001. This expansion accelerated after 2000, with the BOG relative to NOG labor force participation rate falling by an additional 2.02 percentage points between 2001 and 2007. Column 2, which fits the parameterized model in equation (2), shows the rate of divergence between BOG and NOG veterans roughly doubled after the Agent Orange decision, from 0.15 percentage points per year to 0.33 percentage points $(0.15+0.18)$ annually after 2001 .

Coupled with the evidence in Table 5 on DC enrollments, the results in Table 8 suggest that the differential increase in DC enrollment among BOG veterans spurred a reduction in their labor supply. A natural alternative interpretation, however, is that BOG veterans were in worse health than NOG veterans - perhaps due to the rigors of in-theatre military service-leading to comparatively earlier retirements in the 2000 s for reasons unrelated to the 2001 policy change. If so, the accelerating decline in LFP among BOG veterans after 2001 should primarily impact the oldest Vietnam veterans, with younger 
veteran cohorts exhibiting a similar LFP falloff as they approached these early retirement years in subsequent years. Figure 7 and the remaining two panels of Table 8 explore these competing hypotheses by again subdividing the sample into two birth cohorts of average ages 54 and 51 years at the time of the policy change. Both the figure and the table reveal that labor force participation of BOG relative to NOG veterans for both sets of birth cohorts dropped sharply soon after the policy change. The year-over-year decline in BOG LFP relative to NOG LFP doubled after 2001 for both older (born 1946-48) and younger (born 1949-1951) cohorts, rising from 0.17 to 0.36 percentage points $(0.17+0.19)$ among the former group, and from 0.14 to 0.32 percentage points $(0.14+0.18)$ among the latter group. This trend break in BOG relative to NOG labor force participation occurring simultaneously across birth cohorts after 2001 suggests that benefits expansion rather than early retirements explains the sharp drop in BOG labor force participation following the Agent Orange decision.

The upper panel of Table 9 explores these employment patterns by race and AFQT subgroup. Declines in LFP generally mirror uptake of DC across demographic groups. Consistent with the Table 6 findings for DC enrollment, the fall in labor force participation among nonwhite and among low-AFQT BOG relative to NOG veterans following the 2001 policy change is more pronounced than among white and higher-AFQT veterans. These differences across groups are not statistically significant, however.

\section{B. Impacts on labor market earnings}

Alongside its extensive margin impact, receipt of DC benefits may spur veterans to reduce their work hours or switch from full to part-time employment, thus reducing earnings conditional on ongoing employment. We explore the effect of the Agent Orange policy on total labor force earnings by estimating equation (2) for the log of mean cell earnings, excluding (of necessity) cells where all veterans have exited the labor force. ${ }^{39}$ Panel B of Table 9 shows that earnings averaged about 2.6 log points lower

\footnotetext{
${ }^{39}$ We use the log of the mean rather than the mean of the log because of the cell-level aggregation of our earnings data. We do not, however, adjust cell means for non-participation; if a cell contains five veterans each earning $\$ 25 \mathrm{~K}$ annually and one leaves the labor force, mean cell earnings falls to $\$ 20 \mathrm{~K}$. Thus, this measure incorporates intensive and extensive margin adjustments.
} 
among BOG than NOG veterans in our baseline year, and this gap was expanding by about 0.2 log points per year through 2001 . The earnings gap grew significantly more rapidly—by about 0.7 log points annually $(0.23+0.45)$ - following the 2001 policy change. Once again, the effects are larger for nonwhite and low-AFQT veterans.

Since these total earnings impacts combine extensive margin (participation) and intensive margin (hours and wage) responses, we cannot directly infer whether they reflect changes in earnings among incumbents or merely a reduction in the number of veterans working. The evidence in panel A of Table 9 suggests, however, that minority and low-AFQT veterans were particularly likely to exit the labor force upon receiving DC benefits. If we hypothesize more generally that veterans with lower potential earnings are most likely to exit the labor force in response to increased transfer income, we can compare extensive margin and total earnings responses to assess evidence for intensive margin responses. Concretely, suppose that earnings among those dropping out of the labor force are below the average of those still working within the cell — that is, income effects are larger for low earnings workers. In this case, the decline in log cell earnings will be smaller than the decline in log cell labor force participation. Conversely, if the decline in log cell earnings exceeds the decline in log cell participation, this indicates that either earnings is also falling on the intensive margin or, contrary to our assumption, higher earning workers are exiting employment disproportionately.

To facilitate earnings and employment comparisons, panel $\mathrm{C}$ of Table 9 reports estimates where the dependent variable is the log of the fraction of veterans in a cell working (rather than simply the percentage working, as in panel A). Comparing across panels B and $\mathrm{C}$ reveals that the decline in relative earnings of BOG versus NOG veterans after 2001 is, in most cases, slightly larger than the relative decline in labor force participation. In column 1, for example, the relative decline in log earnings of BOG relative to NOG veterans expands by 0.45 log points per year after 2001 whereas the relative decline in $\log$ LFP increases by only $0.36 \log$ points per year. This pattern also holds for black and white veterans considered separately, though it does not hold for lower and higher-AFQT veterans. We infer that the Agent Orange policy likely induced a mixture of labor force exit and earnings reductions among 
beneficiaries, though the evidence on the latter margin is far from clear cut.

\section{Comparing Labor Supply and Enrollment Impacts: Instrumental Variables Estimates}

Motivated by the evidence that the Agent Orange policy both raised DC enrollment and lowered earnings among eligible veterans, we now use the Agent Orange policy as an instrumental variable for receipt of DC benefits. This instrumental variables approach provides a valid estimate of the causal effect of DC benefits on labor supply under the assumption that the Agent Orange policy only affects employment and earnings through its impact on benefits enrollment and transfer payments. This exclusion restriction is untestable of course, but the panoply of findings above confer credibility: we find a sharp rise in DC receipt, DC payments, and total disability income among BOG relative to NOG veterans following adoption of the Agent Orange policy; the rise in take-up was equally steep and pronounced among younger and older veterans, and was greatest among nonwhite and low-AFQT veterans; and in all cases, take-up responses are paralleled by differential employment and earnings drops among BOG relative to NOG veterans that occur among both older and younger veterans, and which are slightly more pronounced among nonwhite and low-AFQT vets.

Table 10 presents instrumental variables of equation (2) for the impact of DC participation on labor force participation, where the endogenous variable in panel A is the percentage of a cell enrolled in DC. ${ }^{40}$ The 2SLS estimate in column (1) finds that each percentage point increase in DC enrollment reduces the fraction of veterans working by 0.18 points - that is, approximately one veteran exits the labor force for every five veterans newly awarded DC benefits. Comparing across rows of this table, we find slightly larger employment effects for nonwhite and low-AFQT veterans, consistent with our maintained hypothesis that participation among these groups is more elastic. Notably, the (scaled) labor force participation impact is estimated to be slightly (though not significantly) larger for younger than older

\footnotetext{
${ }^{40}$ We limit the sample to the years 1998 through 2006 for which DC measures are available, rather than the longer sample window of 1996 through 2007 for which SSA earnings data are available. The instrumental variable for DC enrollment is $B O G_{j} \times(t-2001) \times 1[t \geq 2002]$.
} 
veterans, again underscoring that the results are unlikely to be simply driven by differential trends in early retirement among BOG relative to NOG veterans.

By specifying DC participation as the endogenous variable, the panel A estimate does not account for policy-induced increases in DC benefits along the intensive margin—higher benefits among incumbents, and greater potential benefits among new enrollees. We relax this restriction in panel B by making our endogenous variable the sum of disability income (DC, SSDI and SSI benefits). This variable captures changes in transfer payments among both new enrollees and incumbents. ${ }^{41}$ The panel B estimates find that each thousand dollars in disability benefits payment reduces the probability of a veteran working by approximately 0.80 percentage points, with slightly larger impacts among nonwhite veterans (0.97 points) and slightly smaller impacts among older veterans ( 0.70 points). Scaling these estimates by the mean rate of labor force participation (84.7 points) and mean year 2000 earnings (in constant $\$ 2013$ dollars) of \$52.5K (Appendix Table 4) implies an extensive margin labor force participation elasticity of -0.50 . This is similar in magnitude to the estimates reported by Boyle and Lahey (2010), who study the labor supply of a relatively comparable set of veterans who were nearing retirement in the mid-1990s. We also cannot rule out that the participation elasticity we obtain incorporates both pure (non-incentive) income effects from increased transfer income and additional incentive effects stemming from the potential availability of IU and SSDI benefits. Fully distinguishing these incentive and non-incentive effects remains a ripe topic for future work.

To what degree is this causal effect driven by changes in labor force participation among incumbent DC recipients - many of whom received a higher combined disability ratings and corresponding benefit increases as a consequence of the Agent Orange policy—rather than by changes in participation among new enrollees? Appendix Table 5 probes this question by comparing the evolution of CDRs among veterans according to DC enrollment status as of 1998 (the earliest year for which we have enrollment

\footnotetext{
${ }^{41}$ Because cells receive no disability payments in a given year, we specify the disability payment measure in real dollars rather than taking the logarithm.
} 
data). Column 1 reports estimates of equation (2) for all veterans in our sample where the left hand side variable is a veteran's combined disability rating. Column 2 includes only veterans enrolled in the DC program as of 1998, while column 3 excludes veterans not enrolled in DC as of 1998. Comparing the column 2 and 3 estimates reveals that CDRs were increasing more rapidly among 1998 BOG incumbent DC recipients than among their NOG counterparts prior to the policy change, but that there is only a modest acceleration in this trend after 2001. Specifically, CDRs were increasing by about 0.8 percentage points more annually among the BOG incumbents than the NOG incumbents between 1998 and 2001, and this differential increased only modestly to 1.1 percentage points annually from 2002 forward $(0.84+$ 0.26). In contrast, the acceleration among new BOG entrants after 2001 (column 2) is much larger, increasing from 0.20 to about 1.0 percentage points annually after $2001(0.22+0.73)$. Thus the Agent Orange policy change generated a much larger impact on the DC status of BOG veterans who had not already enrolled in DC prior to the policy change than it did on incumbent recipients, suggesting that labor supply impacts are likely driven primarily by new DC entrants.

Panel B of Appendix Table 5 complements this evidence by comparing labor force participation trends between cells with a high density of DC incumbents and those with a low density of DC incumbents. ${ }^{42}$ Column 1 reports estimates of equation (2) for all veterans in our sample, while column 2 restricts our sample to cells where at least one third of veterans ("high density") were enrolled in DC as of 1998 and column 3 restricts our sample to cells where less than one third of veterans ("low density") were enrolled in DC as of $1998 .^{43}$ Following the 2001 policy change, the rate of divergence among BOG relative to NOG veterans actually attenuated slightly for cells with a high density of incumbents (from 0.35 to 0.29 points per year), but nearly tripled for cells with a low density of incumbents (from 0.11 to

\footnotetext{
${ }^{42}$ While the SSA outcome cells never combine BOG and NOG veterans, they often combine a mixture of DC and non-DC enrollees, and this fraction changes over time as enrollment evolves. It would have been invalid to construct cells based on eventual DC enrollment, of course, since DC enrollment is an outcome of the analysis.

${ }^{43} \mathrm{We}$ cannot fully distinguish labor force participation effects for incumbents and potential entrants because labor force participation rates are determined at the cell level and cells are not stratified on DC enrollment. For example, consider a cell with two veterans who were enrolled in DC as of 1998 and three veterans who were not enrolled as of 1998. If all five veterans had positive earnings in 1998, but only four had positive earnings as of 2006, we are unable to determine whether the veteran who dropped out of the labor force was enrolled in DC as of 1998 or not.
} 
0.32 points per year). This pattern again suggests that the differential decline in labor force participation among BOG relative to NOG veterans after 2001 is driven primarily by veterans induced to enroll in DC by the Agent Orange policy rather than by policy-induced changes in behavior among incumbent recipients.

\section{Impacts on Total Earnings}

Since the Agent Orange policy precipitated a rise in transfer payments and fall in employment and earnings among eligible veterans, its net impact on incomes of BOG relative to NOG veterans is ambiguous. We compare trends in total measured income (earnings plus the sum of DC, SSDI and SSI benefits) between BOG and NOG veterans in Table 11, again limiting to the years 1998 through 2006, where we have all earnings and benefits variables available. Since we have already established that employment and earnings respond endogenously to policy-induced shifts in disability transfer income (as theory would predict), the current exercise should be viewed as descriptive rather than inferential; the net impact of the Agent Orange policy on veterans' income combines exogenous policy impacts and endogenous behavioral responses.

The first column of Table 11 (panel A) shows that, at the start of sample window in 1998, measured incomes of BOG veterans were slightly lower than those of NOG veterans, with gaps of 0.75 log points overall, $0.80 \log$ points among nonwhites, and $0.70 \log$ points among whites. ${ }^{44}$ Notably, incomes were significantly higher (by 3.7 log points) among low-AFQT BOG veterans and significantly lower (by 2.5 log points) among high-AFQT BOG veterans (relative to their NOG counterparts). Recall, we saw earlier in panel B of Table 9 that labor earnings of BOG veterans averaged up to 5 log points below that of NOG veterans. Thus, comparing Tables 9 and 11 reveals that disability transfer income largely made up the difference between BOG and NOG veterans, and resulted in substantially higher income for low-AFQT BOG veterans relative to low-AFQT NOG veterans, consistent with the findings of Angrist et al (2010)

\footnotetext{
${ }^{44}$ These reported earnings are covariate adjusted since they derive from the Table 11 regression estimates. Raw differences are similar, however, as may be inferred from Table 3.
} 
for low-education veterans.

The second and third rows of Table 11 summarize the evolution of the BOG/NOG income differential before and after the Agent Orange policy. Prior to the policy change, BOG veterans were on a slightly more positive total income trend than NOG veterans, with average annual incomes in the full sample rising by $0.20 \log$ points annually in relative terms. This differential trend steepened significantly following the policy change, jumping from 0.20 to $0.71 \log$ points $(0.20+0.51)$ annually. For nonwhites and low-AFQT veterans, the increase in the trajectory was steeper, rising from 0.27 to 1.31 log points annually for the former group, and from 0.33 to $1.19 \log$ points for the latter. While the Agent Orange policy sharply reduced employment and earnings among eligible veterans, the Table 11 estimates make clear that the policy-induced rise in transfer income more than offset these earnings reductions.

As a final characterization of these net policy and behavioral effects, the lower panel of Table 11 summarizes the net impact of DC enrollment on total earnings, where DC enrollment is instrumented with the Agent Orange policy. The outcome variable for these estimates is cell total income-earnings plus disability benefits - and the endogenous variable is again DC enrollment. The point estimate of 0.52 for the full sample implies that - if a cell increased from 0 to 20 percent enrolled in DC - then average total veteran income in the cell would increase by about 10.4 percent. In interpreting this sizable impact, note that we found above that only one in five (18 percent of) newly enrolled veterans exited the labor force as a consequence of the Agent Orange policy. For the remaining four-fifths, enrollment in DC raised transfer income while generating only minimal offsetting reductions in labor income, thus unambiguously raising total income. Of course, average incomes of Vietnam era veterans were modest in the early 2000s and remained modest net of transfer benefits following the Agent Orange policy change. Nevertheless, this policy had the unusual effect of increasing average veteran incomes, inclusive of the foregone earnings of the approximately one in five newly enrolled DC recipients induced to exit the labor force.

\section{Discussion}

This paper provides evidence that the policy-induced increase in enrollment in the VA's Disability 
Compensation program had a significant effect on the labor supply of Vietnam-era veterans. We estimate that 18 percent of individuals who became eligible for the DC program as a result of the policy change dropped out of the labor force. Analyses that explore the effect on average earnings support the conclusion that DC enrollment substantially lowered labor supply among Vietnam-era veterans who served in the Vietnam theatre during the conflict there. These effects appear to be driven by those made newly eligible for DC benefits rather than by increases in benefits among those already receiving DC prior to the 2001 policy change. The increase in transfer income more than offsets the reduction in earnings, so that average income among BOG veterans increased relative to their counterparts who did not serve in theatre. Combining policy-induced increases in transfer income and reductions in labor force participation, we estimate an extensive margin labor supply elasticities of -.50 , which is somewhat larger than consensus estimates, though not implausible for this near-elderly population of Vietnam era veterans in diminished health.

It is also likely that the income effect of DC income on employment and earnings is augmented by the interaction between DC enrollment and veterans' potential eligibility for Individual Unemployability and SSDI benefits, both of which provide strong incentives against gainful labor force participation. Consistent with this hypothesis, we find that the Agent Orange decision affected enrollment in two other federal disability programs, raising enrollment in SSDI by approximately one recipient for every ten veterans newly enrolled in DC, and slightly reducing enrollment in the means-tested SSI program (though the estimated effects are an order of magnitude smaller than for SSDI). In addition, 14 percent of Vietnam era veterans within our sample received IU status by 2006. Among veterans who enrolled in DC the year after the Agent Orange policy change, fully one-third received IU status or a CDR of 100 by 2006 . Since IU benefits are only available to veterans with earnings at or below the poverty threshold for a single individual, the rapid growth of IU designations among newly enrolled DC beneficiaries underscores the potential for the graduated DC benefit program to generate unintended labor supply impacts. Analyzing the dynamic interaction between these incentive and non-incentive effects of disability benefit programs is a worthy goal for future research. 


\section{Data Appendix}

\section{A. Construction of Cells in the BOG and NOG Samples}

To construct cells for matching individuals in the BOG and NOG samples with SSA data, we group individuals based on their values of certain background characteristics, including their gender, race, year of birth, and so forth. The list of variables used to form cells, ranked in the order in which the grouping occurred, is as follows:

1. Gender (male or female)

2. Race (white or nonwhite)

3. Death year (e.g. 1985)

4. Year-of-birth (e.g. 1946)

5. Start year (e.g. 1966)

6. Education at entry (e.g. 0, 1, 2, 3, 4 for hsd, hsg, smc, clg, clg-plus)

7. AFQT score quintile (e.g. 2)

8. Loss year (e.g. 1972)

9. Region of residence (e.g. Northeast)

Before forming cells, we determined which individuals could be verified upon matching to the SSA data. A match would be verified if the social security number, date of birth, and at least six letters of the last name could be matched in the two data sets. We construct cells from the verified BOG and NOG samples so that there are between five and nine individuals in each cell. Each cell consists only of individuals in the BOG or in the NOG. The number of variables used in the grouping varies across cells. This occurs because in some cases, a cell reaches a size of five to nine after grouping on a relatively small number of variables. If a cell is between 10 and 29 individuals, we do not split further, but instead split the cell into the maximum number of cells with size five or more after sorting on the next matching variable to maximize similarity within the cells. If a cell has fewer than five individuals then we re-merge it with an adjacent cell. If a cell with fewer than five individuals is merged with an adjacent cell to form a new cell with more than nine individuals, the merged cell is split in two.

The distribution of the cell size for the verified NOG sample is:

\begin{tabular}{|c|c|c|}
\hline In Cell of Size & Frequency & Percentage \\
\hline 5 & $1,388,440$ & 58.86 \\
\hline 6 & 657,696 & 27.88 \\
\hline 7 & 171,269 & 7.26 \\
\hline 8 & 70,048 & 2.97 \\
\hline 9 & 71,271 & 3.02 \\
\hline Total & $2,358,724$ & 100.00 \\
\hline
\end{tabular}

The corresponding distribution for the verified BOG sample is:

\begin{tabular}{|c|c|c|}
\hline In Cell of Size & Frequency & Percentage \\
\hline 5 & 942,415 & 65.19 \\
\hline 6 & 328,338 & 22.71 \\
\hline 7 & 92,785 & 6.42 \\
\hline 8 & 41,120 & 2.84 \\
\hline 9 & 40,878 & 2.83 \\
\hline Total & $1,445,536$ & 100.00 \\
\hline
\end{tabular}


The frequency distribution for the number of variables used in the BOG and NOG cell formation is as follows (thus 206,780 in the BOG matched on variables 1 through and including 8):

\begin{tabular}{|c|c|c|}
\hline Number of Vars & \# in NOG & \# in BOG \\
\hline 1 & 0 & 0 \\
\hline 2 & 89 & 61 \\
\hline 3 & 3,391 & 4,149 \\
\hline 4 & 38,087 & 30,716 \\
\hline 5 & 86,671 & 62,807 \\
\hline 6 & 80,909 & 65,140 \\
\hline 7 & 174,281 & 162,909 \\
\hline 8 & 397,667 & 206,780 \\
\hline 9 & $1,577,629$ & 912,974 \\
\hline Total & $2,358,724$ & $1,445,536$ \\
\hline
\end{tabular}

\section{B. Construction of the Analysis Sample}

Appendix Figure 1A diagrams the construction of the sample used in our analysis. The "loss year" file and the Vietnam file combine to form our baseline OEMA sample of 4.1 million veterans. After merging the OEMA sample to VA disability data, the SSA Death Master File, and SSA earnings information, we restrict our sample to 3.8 million veterans who had valid SSA earnings data. As seen in Table 2, the number of BOG veterans in our database is largest in the 1966 through 1971 start years; veterans who began their service after 1971 tended not to serve in the Vietnam theatre while those entering before 1966 are much less likely to be included in our sample since many in the latter group left the Army prior to 1968 , the first year of our "loss year" file. We therefore restrict both the BOG and NOG samples to veterans who have a start year between 1966 and 1971 inclusive, which reduces our sample to 1.9 million veterans. ${ }^{45} \mathrm{We}$ further restrict attention to individuals born between 1946 and 1951 inclusive, with 1.5 million veterans remaining. We next exclude approximately 150,000 veterans who have missing loss years, loss years before 1968, or loss years after 1985. We finally drop an additional 8,000 veterans who are in SSA cells where not all veterans have the same birth year, at least one veteran in the cell has a start year before 1966 or after 1971, or at least one veteran in the cell has a loss year before 1968 or after 1985. Our final sample includes 1.351 million veterans of the U.S. Army who began their service between 1966 and 1971 and were born between 1946 and 1951. For the analysis, we converted this final sample into a 1996-2007 panel of 15.2 million (year) x (individual) observations, or 2.9 million (year) x (cell) observations, as depicted in Appendix Figure 1B. ${ }^{46}$

\footnotetext{
${ }^{45}$ For the nearly 200,000 veterans with missing start years, we imputed their start year based on the median start year for other veterans in the sample with the same date of birth. This has little bearing on our final sample as nearly all veterans with missing start years have missing loss years and are therefore excluded from our analysis.

${ }^{46} \mathrm{~A}$ veteran who dies in year $t$ is dropped from the analysis sample in year $t$ and in all subsequent years. Because year-of-death is one of the variables used when constructing cells, typically all members of a cell die in the same year (if any die). The number of surviving cells falls by approximately 4.8 percent from 1996 to 2007 . We restrict our panel to 1998 through 2006 for all specifications where the outcome is based on VA disability data.
} 


\section{References}

Abbott, Michael and Orley Ashenfelter. 1976. "Labour Supply, Commodity Demand and the Allocation of Time," Review of Economic Studies, 43(3), 389 - 411.

Air Force Health Study. 2000. "Air Force Health Study: An Epidemiological Investigation of Health Effects in Air Force Personnel Following Exposure to Herbicides. 1997 Follow-up Examination Results." Brook Air Force Base: Air Force Research Laboratory.

Angrist, Josh, Stacey Chen, and Brigham Frandsen. 2010. "Did Vietnam Veterans Get Sicker in the 1990s? The Complicated Effects of Military Service on Self-Reported Health." Journal of Public Economics, 94(11), 824-837.

Ashenfelter, Orley and James J. Heckman. 1974. "The Estimation of Income and Substitution Effects in a Model of Family Labor Supply.” Econometrica, 42(1), 73-85.

Autor, David H. and Mark G. Duggan. 2003. "The Rise in the Disability Rolls and the Decline in Unemployment." Quarterly Journal of Economics, 118(1), 157-206.

Autor, David H. and Mark G. Duggan. 2007. "Distinguishing Income from Substitution Effects in Disability Insurance." American Economic Review Papers and Proceedings, 97, 119124.

Autor, David H., Mark G. Duggan, and David Lyle. 2011. "Battle Scars? The Puzzling Decline in Employment and Rise in Disability Receipt among Vietnam Era Veterans." American Economic Review Papers and Proceedings, 101, 339-344.

Autor, David H., Nicole Maestas, Kathleen J. Mullen and Alexander Strand. 2014. "Does Delay Cause Decay? The Effect of Administrative Decision Time on the Labor Force Participation and Earnings of Disability Applicants." MIT Working Paper, December.

Bilmes, Linda J. and Joseph E. Stiglitz. 2008. The Three Trillion Dollar War: The True Cost of the Iraq Conflict. New York: W.W. Norton and Company.

Black, Dan, Kermit Daniel, and Seth Sanders. 2002. "The Impact of Economic Conditions on Participation in Disability Programs: Evidence from the Coal Boom and Bust."American Economic Review, 92, 27-50.

Borghans, Lex, Anne Gielen, and Erzo Luttmer. 2014. "Social Support Substitution and the Earnings Rebound: Evidence from a Regression Discontinuity in Disability Insurance Reform.” American Economic Journal: Economic Policy, 6(4), 34-70.

Bound, John. 1989. "The Health and Earnings of Rejected Disability Insurance Applicants." American Economic Review, 79(3), 482-503.

Bound, John and Timothy Waidmann. 1992. "Disability Transfers, Self-Reported Health, and the Labor Force Attachment of Older Men: Evidence from the Historical Record." Quarterly Journal of Economics, 1393-1419. 
Bound, John and Richard Burkhauser. 1999. "Economic Analysis of Transfer Programs Targeted on People with Disabilities." Handbook of Labor Economics, Volume 3 (eds. Orley Ashenfelter and David Card), Amsterdam, North-Holland.

Boyle, Melissa A. and Johanna Lahey. 2010. "Health Insurance and the Labor Supply Decisions of Older Workers: Evidence from a US Department of Veterans Affairs Expansion." Journal of Public Economics, 94(7-8), 467-478.

Calvert, G., Sweeney, M., Deddens, J. and D. Wall. 1999. "An Evaluation of Diabetes Mellitus, Serum Glucose, and Thyroid Function among U.S. Workers Exposed to 2, 3, 7, 8tetrachlorodibenzo-p-dioxin." Occupational and Environmental Medicine, 56(4), 270276.

Chen, Susan and Wilbert van der Klaauw. (2008) "The Work Disincentive Effects of the Disability Insurance Program in the 1990s." Journal of Econometrics, 142(2), 757-784.

Chetty, Raj. 2012. "Bounds on Elasticities with Optimization Frictions: A Synthesis of Micro and Macro Evidence on Labor Supply." Econometrica, 80(3), 969-1018.

Coile, Courtney, and Jonathan Gruber. 2007. "Future Social Security Entitlements and the Retirement Decision." Review of Economics and Statistics, 89(2), 234-246.

Coile, Courtney, Mark Duggan and Andrew Guo. (2015) "Veterans' Labor Force Participation: What Role Does the VA's Disability Compensation Program Play?" forthcoming in American Economic Review Papers and Proceedings.

Duggan, Mark, Perry Singleton and Jae Song. 2007. "Aching to Retire? The Rise in the Full Retirement Age and its Impact on the Disability Rolls." Journal of Public Economics, 91(7), 1327-1350.

Duggan, Mark, Robert Rosenheck and Perry Singleton. 2010. "Federal Policy and the Rise in Disability Enrollment: Evidence for the VA's Disability Compensation Program." Journal of Law and Economics, 53, 379-398.

French, Eric and Jae Song. 2014. "The Effect of Disability Insurance Receipt on Labor Supply." American Economic Journal: Economic Policy, 6(2), 291-337.

Frisch, Ragnar. 1959. "A Complete Scheme for Computing All Direct and Cross Demand Elasticities in a Model with Many Sectors," Econometrica, 27(2), 177-196

Gruber, Jon. 2000. "Disability Insurance Benefits and Labor Supply," Journal of Political Economy, 108, 1162-1183.

Institute of Medicine. 2000. "Veterans and Agent Orange: Herbicide/Dioxin Exposure and Type 2 Diabetes." Washington, D.C.: The National Academies Press.

Kostøl, Andreas and Magne Mogstad. 2014. "How Financial Incentives Induce Disability Insurance Recipients to Return to Work." American Economic Review 104(2): 624-55. 
Maestas, Nicole, Kathleen Mullen, and Alexei Strand. 2013. "Does Disability Insurance Receipt Discourage Work? Using Examiner Assignment to Estimate Causal Effects of SSDI Receipt.” American Economic Review, 103(5), 1797-1829.

McClelland, Robert and Shannon Mok. 2012. “A Review of Recent Research on Labor Supply Elasticities.” Congressional Budget Office Working Paper \#2012-12, October.

Parsons, Donald. 1980. "The Decline in Male Labor Force Participation." The Journal of Political Economy 88: 117-134.

Schiller, Jeannine, Jacqueline Lucas, Brian Ward, Jennifer Peregoy. 2010. "Summary Health Statistics for U.S. Adults: National Health Interview Survey, 2010.” Vital and Health Statistics, 10(252).

U.S. Department of Veterans Affairs. 2003. "Agent Orange Brief.” Environmental Agents Service, (131) A1.

U.S. General Accounting Office. 2006. "VA Should Improve Its Management of Individual Unemployability Benefits by Strengthening Criteria, Guidance, and Procedures.” Report GAO-06-309.

U.S. General Accounting Office. 2009. "Social Security Disability:Additional Outreach and Collaboration on Sharing Medical Records Would Improve Wounded Warriors' Access to Benefits." Report GAO-09-762.

U.S. Veterans Benefits Administration. Selected Years. "Veterans Benefits Administration Annual Benefits Report.” Available online at http://www.vba.va.gov/reports.htm.

Von Wachter, Till, Joyce Manchester, and Jae Song. 2011. "Trends in Employment and Earnings of Allowed and Rejected Applicants to the SSDI Program." American Economic Review, 3308-3329. 
Figure 1. Number and Percentage of Veterans Enrolled in DC

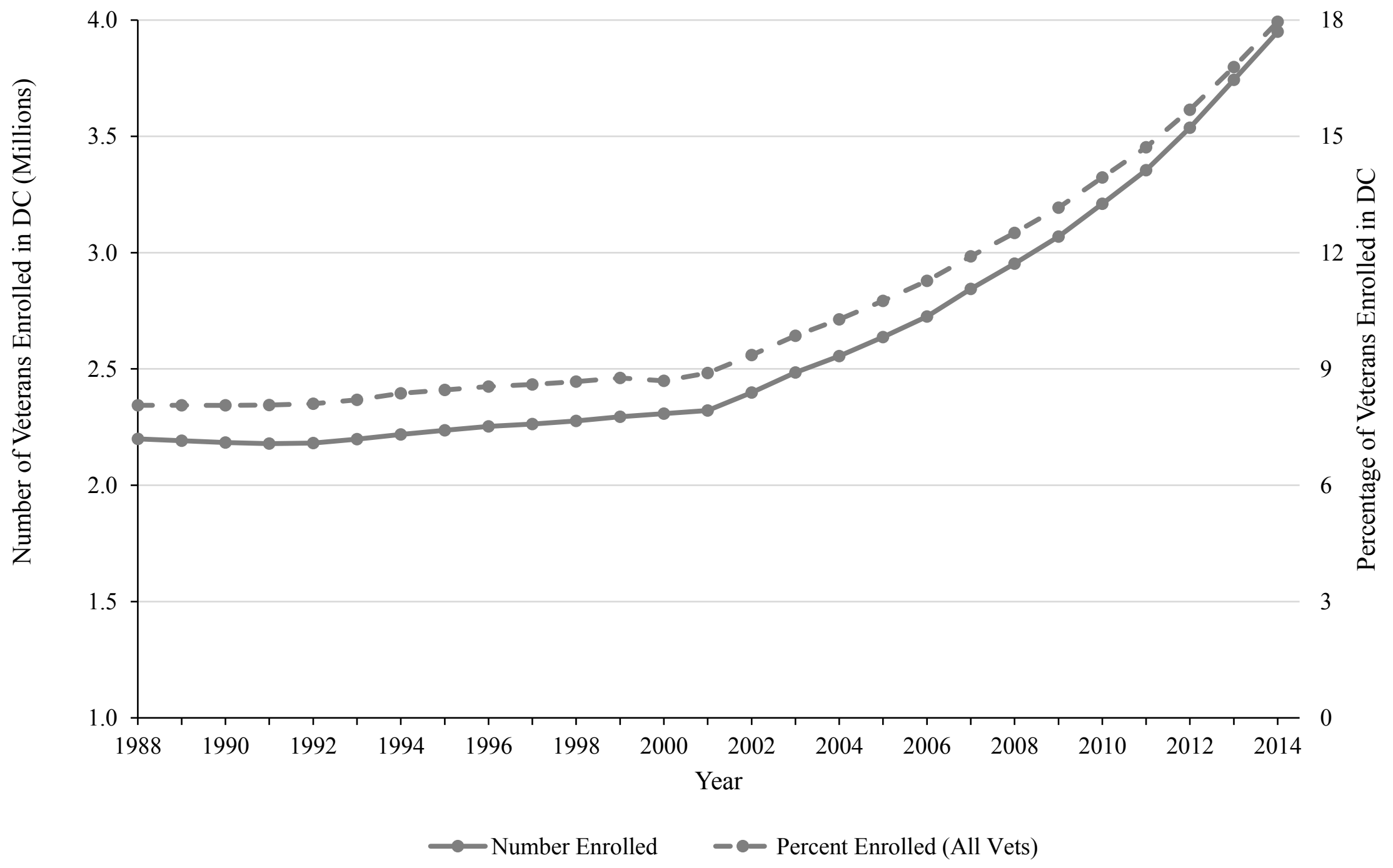

Notes: This figure reports the number of veterans enrolled in the Veterans' Disability Compensation (DC) program (left axis) and the percentage of living veterans enrolled in DC (right axis). Prior to 1999, all data comes from Annual Statistical Abstracts of the United States. From 1999 through 2014, annual DC enrollment numbers are from Veterans' Benefits Administration Annual Reports and the number of veterans in the U.S. comes from VetPop 2007, VetPop2010, and VetPop2014. 
Figure 2. DC Enrollment as a Percentage of Vietnam Era Veterans

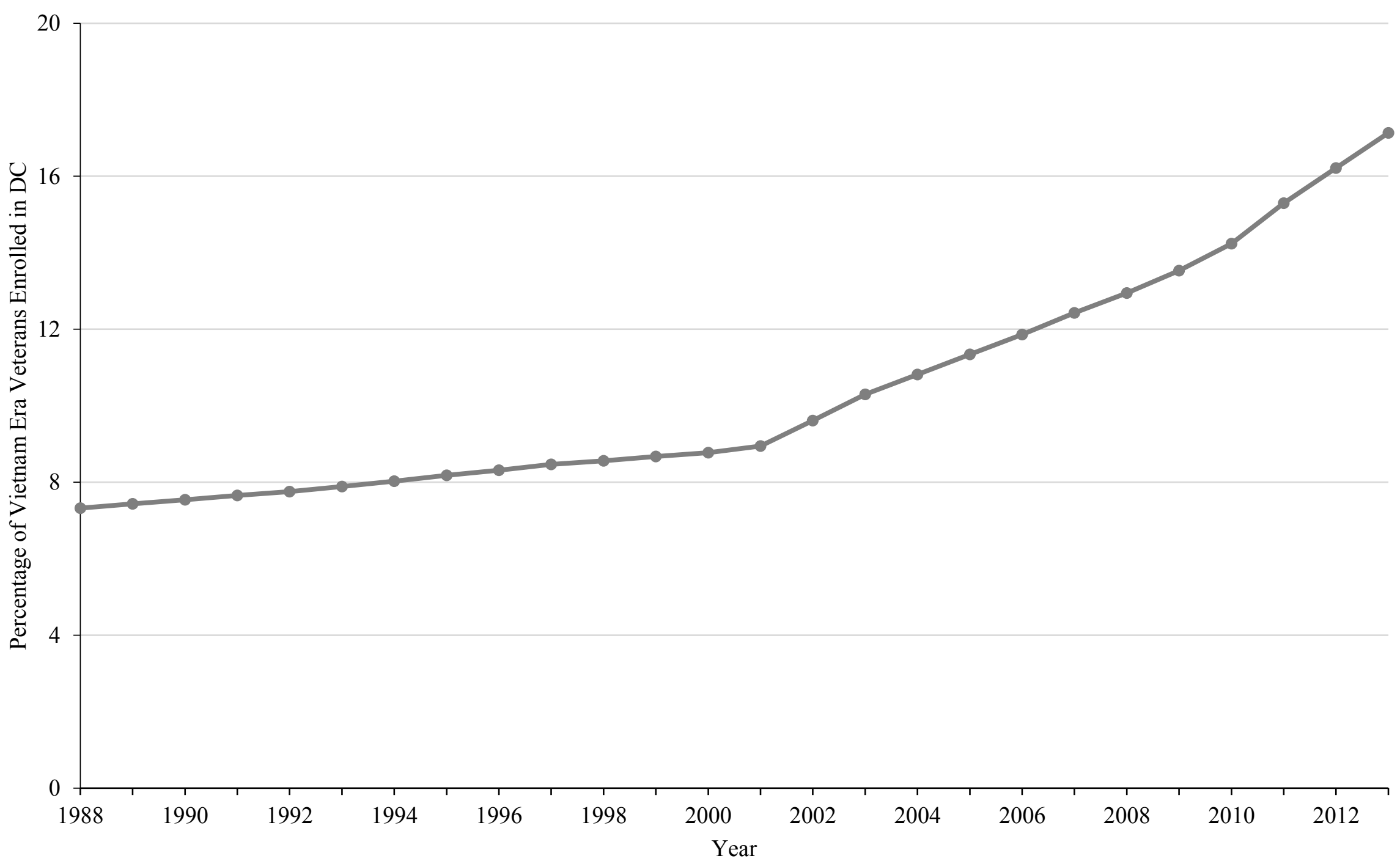

Notes: This figure reports the annual percentage of Vietnam era Veterans who received any DC benefits. See sources from Figure 1. 
Figure 3. Percentage of BOG and NOG Veterans Enrolled in DC

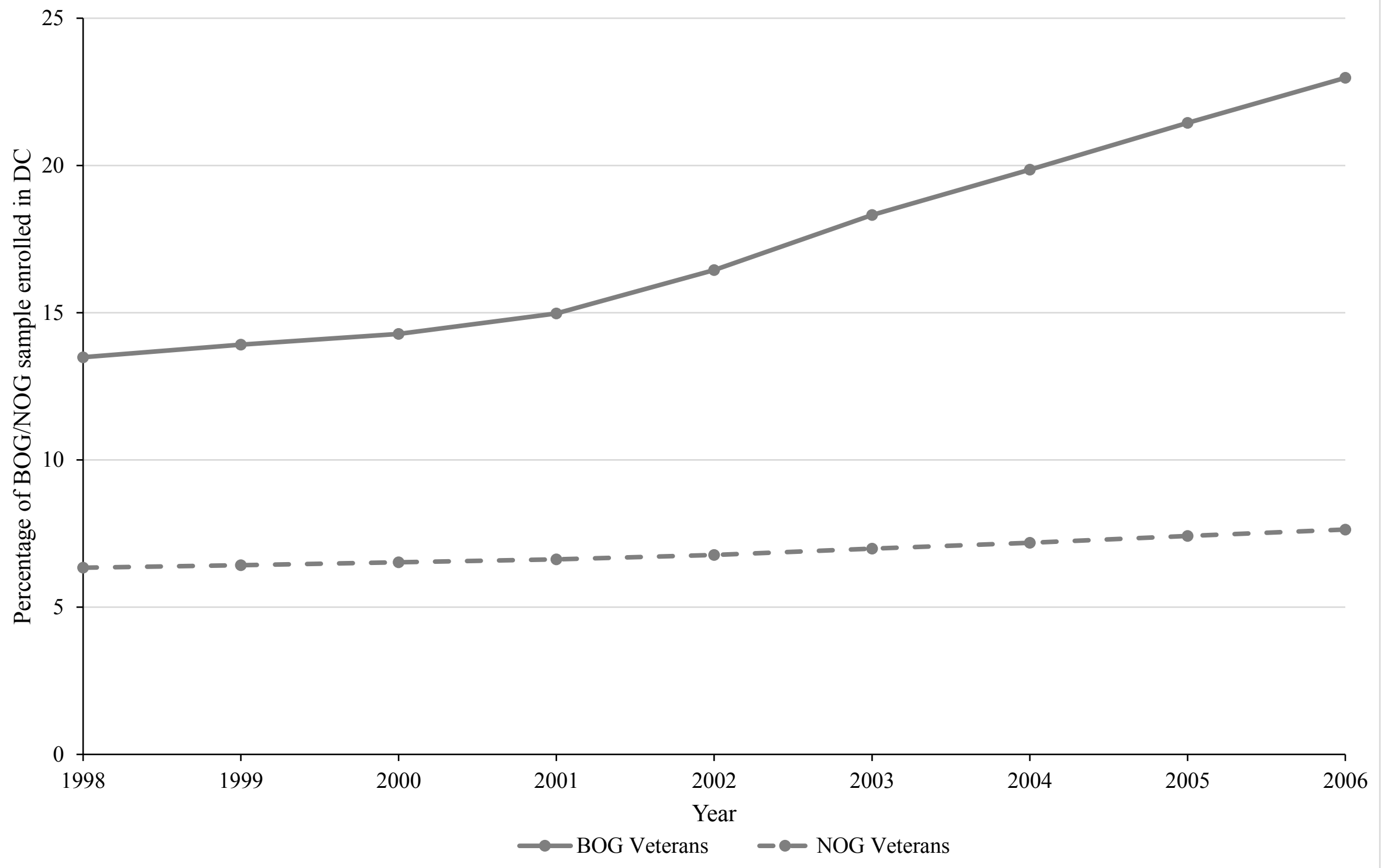

Notes: This table reports the annual percentage of BOG and NOG veterans who received any DC benefits between 1998 and 2006. 
Figure 4. Prevalance of DC Benefits for Diabetes in BOG and NOG Samples

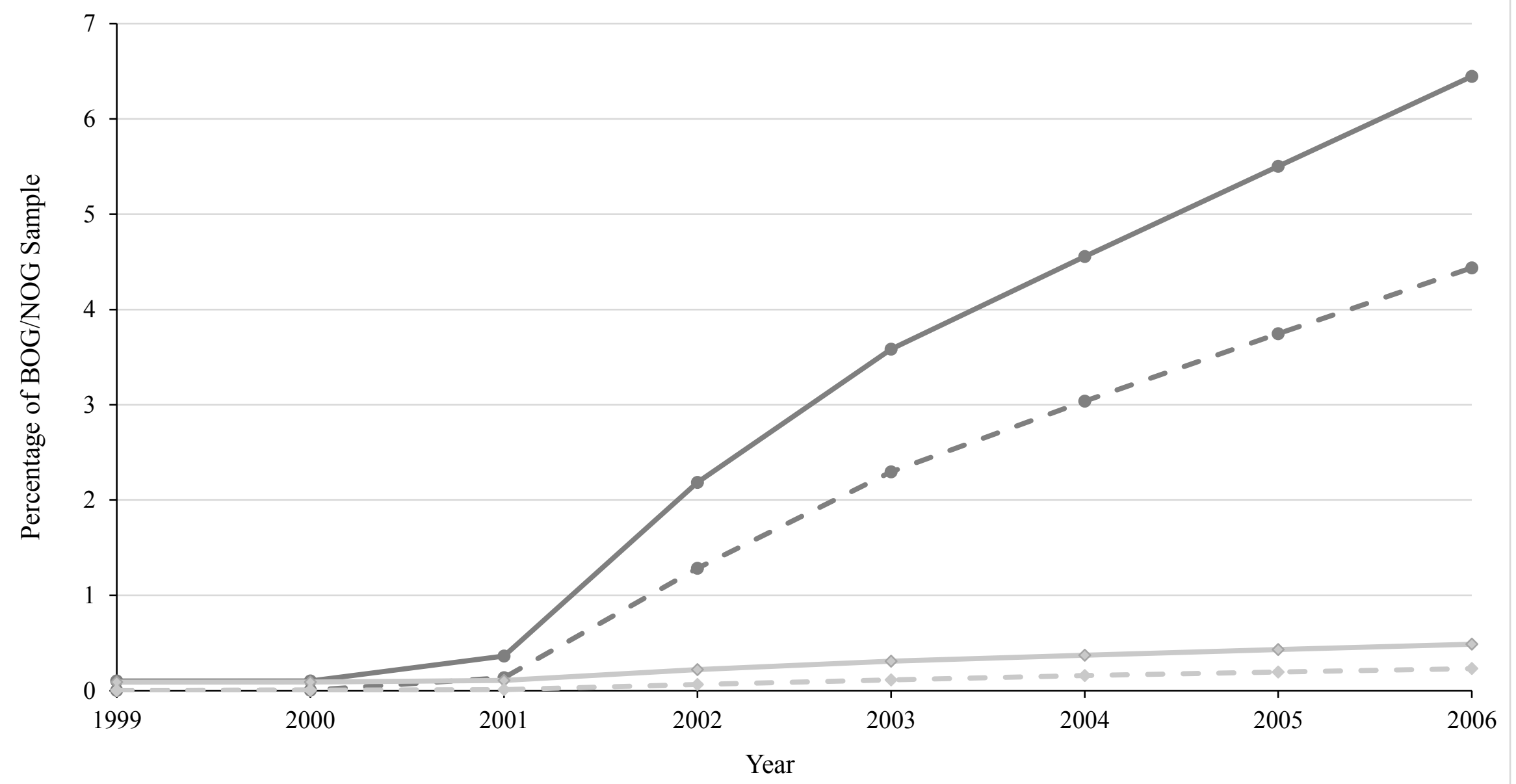

$\longrightarrow$ BOG, Diabetes Benefits

- B BOG, Diabetes Benefits During Year of DC Enrollment

$\leadsto$ NOG, Diabetes Benefits

$-\diamond$ NOG, Diabetes Benefits During Year of DC Enrollment

Notes: This table reports the annual percentage of BOG and NOG veterans who were enrolled in DC and who received DC benefits for diabetes. The series "BOG, Diabetes Benefits During Year of DC Enrollment" refers to the percentage of veterans in the BOG sample who were enrolled in DC, received benefits for diabetes, and began receiving diabetes benefits the same year they enrolled in DC. 
Figure 5. Percentage of BOG and NOG Veterans Enrolled in DC without Diabetes

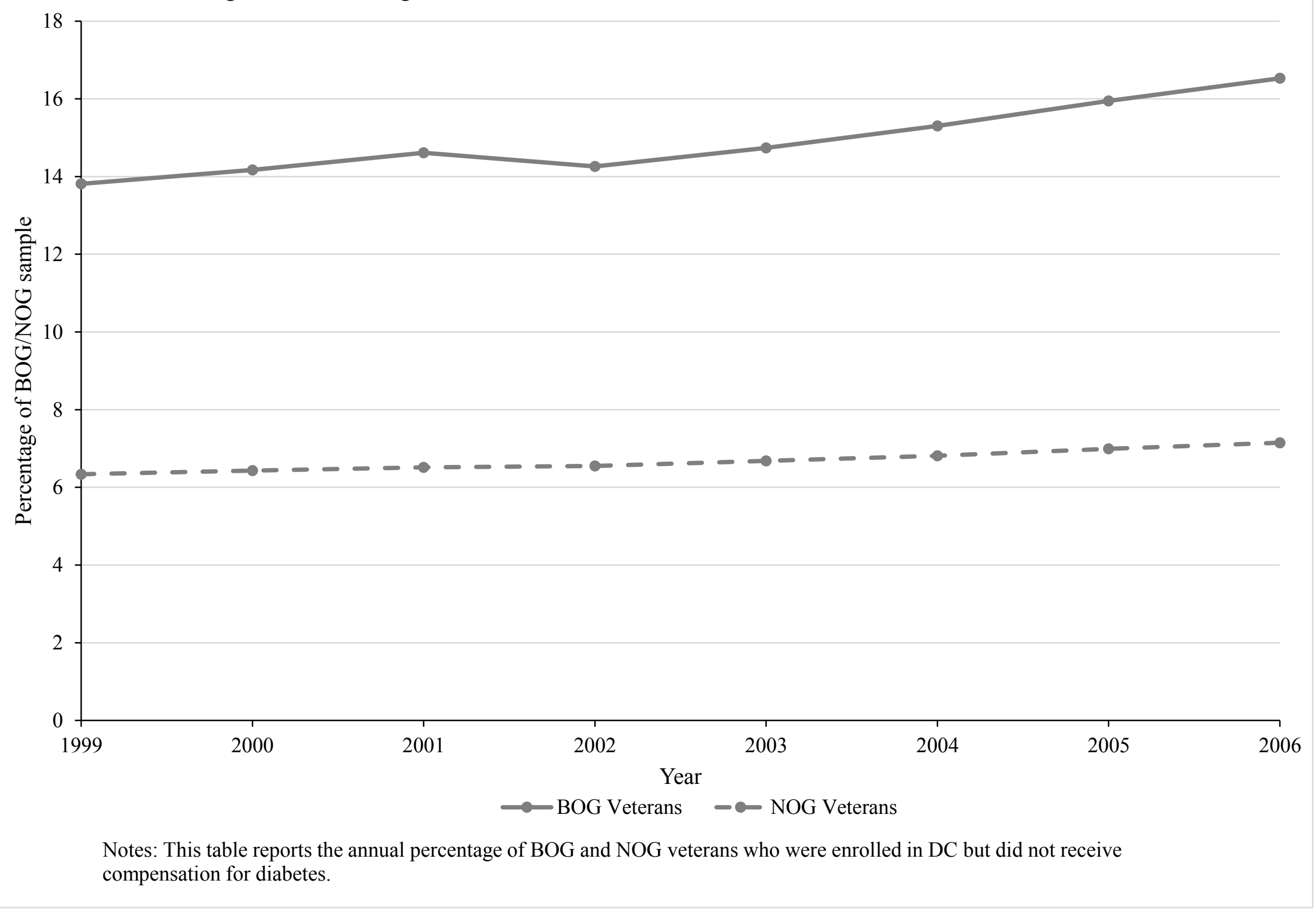


Figure 6. BOG DC Receipt Relative to NOG by Year of Birth Cohort

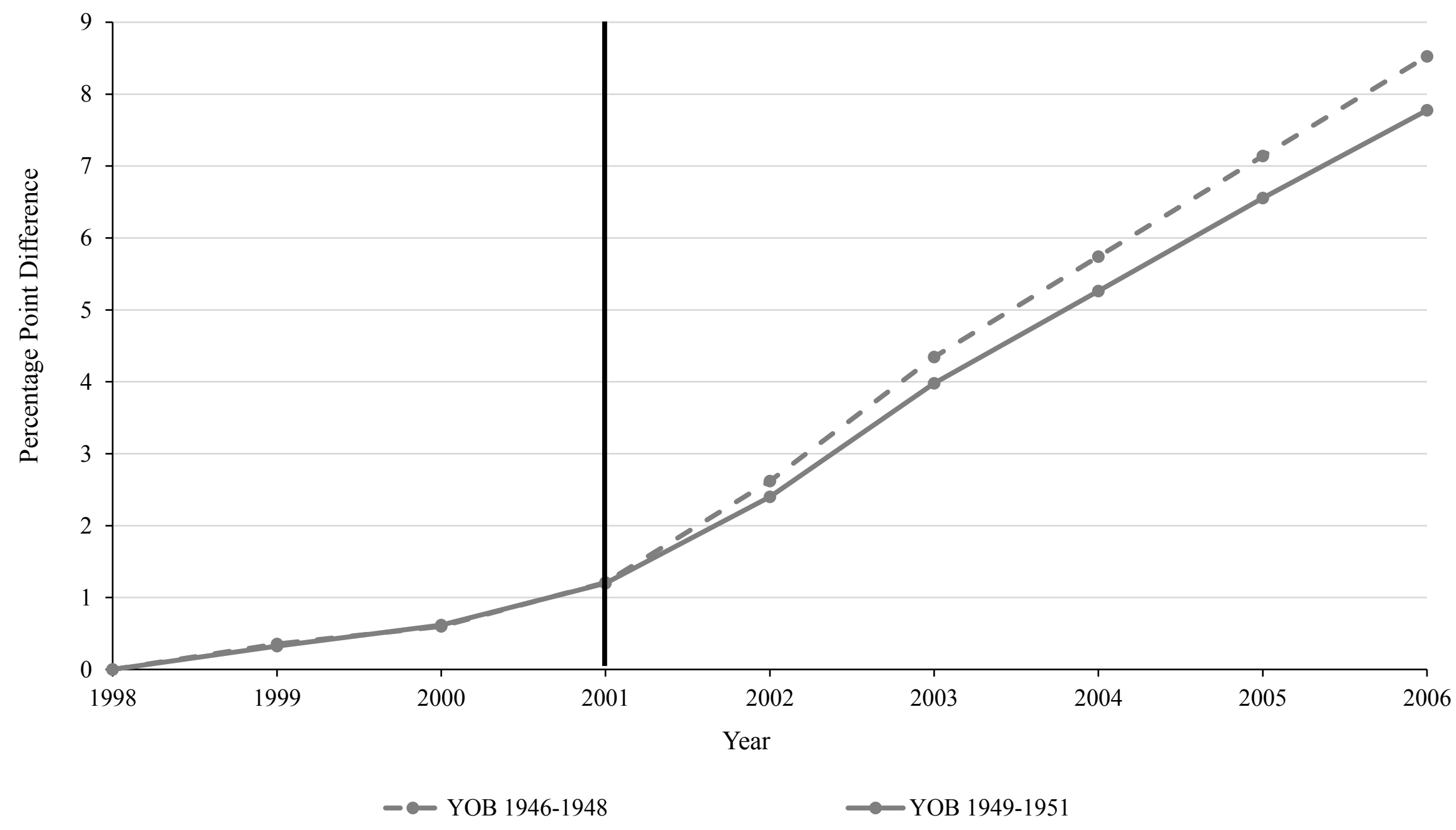

Notes: This table reports the absolute percentage point difference between BOG DC receipt and NOG DC receipt for two veteran birth cohorts: 1946-1948 and 1949-1951. The vertical line indicates the year of the Agent Orange policy change. Each series is normalized to the BOG-NOG difference in DC receipt as of year 1998. 
Figure 7. BOG LFP Relative to NOG by Year of Birth Cohort

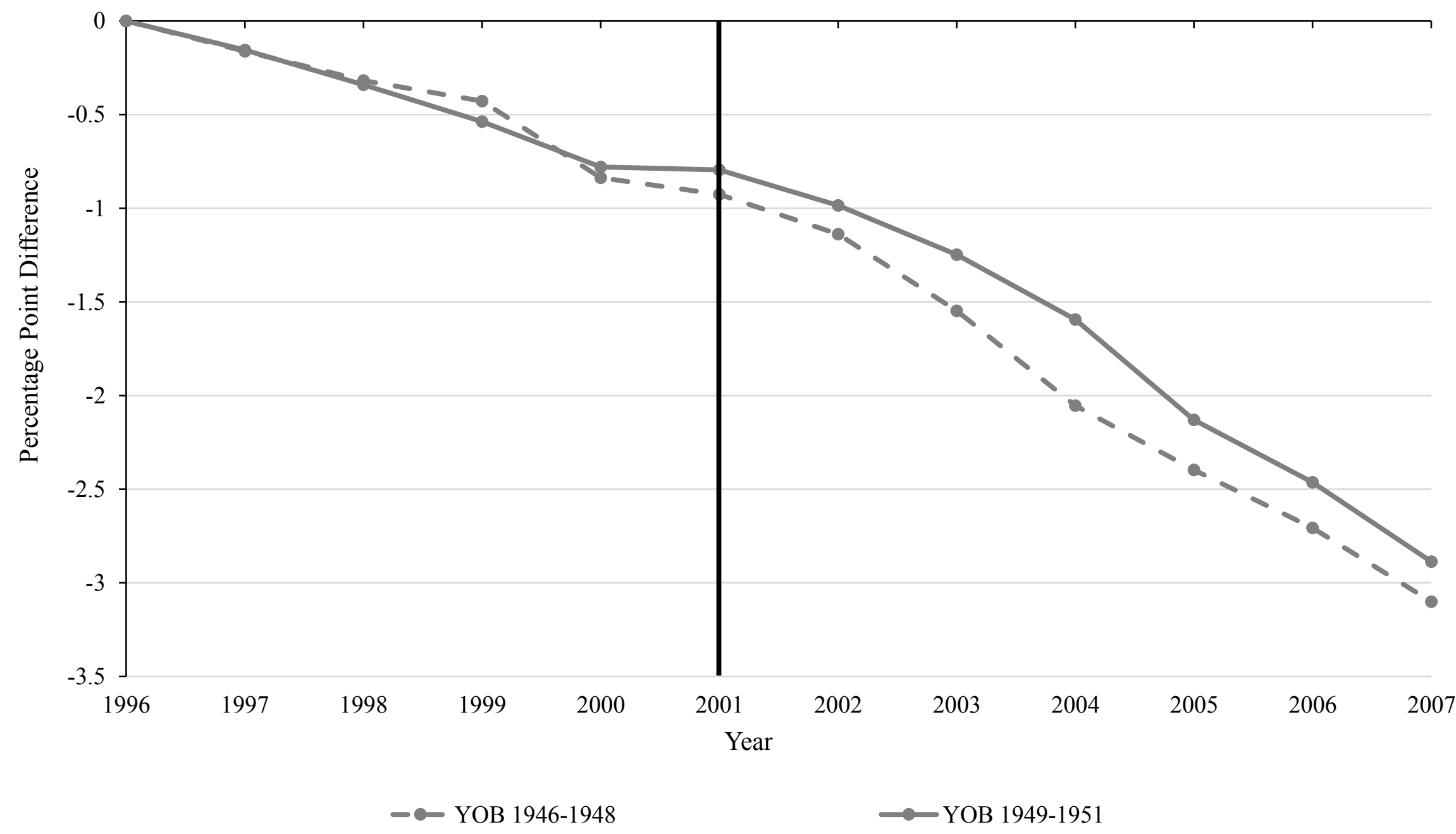

Notes: This table reports the absolute percentage point difference between BOG labor force participation (LFP) and NOG LFP for two veteran birth cohorts: 1946-1948 and 1949-1951. The vertical line indicates the year of the Agent Orange policy change. Each series is normalized to the BOG-NOG difference in LFP as of year 1996. Labor force participation is defined as positive earnings. 
Table 1. Evolution of Disability Compensation (DC) Benefits by Year of DC Enrollment DC Enrollment Cohorts 1999-2006

\begin{tabular}{|c|c|c|c|c|c|c|c|c|}
\hline \multirow{2}{*}{$\begin{array}{c}\text { Year of } \\
\text { Enrollment }\end{array}$} & \multicolumn{8}{|c|}{ Outcome Year } \\
\hline & $\begin{array}{c}1999 \\
(1)\end{array}$ & $\begin{array}{c}2000 \\
(2)\end{array}$ & $\begin{array}{c}2001 \\
(3)\end{array}$ & $\begin{array}{c}2002 \\
(4)\end{array}$ & $\begin{array}{c}2003 \\
(5)\end{array}$ & $\begin{array}{c}2004 \\
(6)\end{array}$ & $\begin{array}{c}2005 \\
(7)\end{array}$ & $\begin{array}{c}2006 \\
(8)\end{array}$ \\
\hline \multicolumn{9}{|c|}{ A. Mean Combined Disability Rating } \\
\hline 1999 & 41.8 & 45.5 & 49.7 & 53.5 & 57.7 & 60.3 & 62.3 & 63.6 \\
\hline 2000 & & 44.1 & 50.0 & 55.0 & 59.4 & 62.3 & 64.6 & 66.3 \\
\hline 2001 & & & 41.2 & 46.2 & 52.3 & 56.6 & 60.6 & 62.6 \\
\hline 2002 & & & & 38.7 & 46.0 & 50.9 & 54.8 & 57.6 \\
\hline 2003 & & & & & 41.8 & 47.8 & 52.2 & 55.2 \\
\hline 2004 & & & & & & 43.0 & 48.5 & 51.5 \\
\hline 2005 & & & & & & & 41.3 & 45.1 \\
\hline 2006 & & & & & & & & 39.1 \\
\hline \multicolumn{9}{|c|}{ B. Mean Annual DC Payment (\$2013) } \\
\hline 1999 & 10,773 & 12,577 & 14,389 & 15,734 & 17,325 & 18,347 & 19,083 & 19,822 \\
\hline 2000 & & 11,714 & 14,295 & 16,090 & 17,756 & 18,923 & 19,799 & 20,701 \\
\hline 2001 & & & 10,709 & 12,603 & 14,991 & 16,715 & 18,329 & 19,317 \\
\hline 2002 & & & & 9,611 & 12,432 & 14,368 & 15,878 & 17,153 \\
\hline 2003 & & & & & 10,650 & 13,007 & 14,735 & 16,099 \\
\hline 2004 & & & & & & 11,114 & 13,222 & 14,521 \\
\hline 2005 & & & & & & & 10,335 & 11,922 \\
\hline 2006 & & & & & & & & 9,590 \\
\hline \multicolumn{9}{|c|}{ C. Percentage Receiving IU Award or 100 CDR } \\
\hline 1999 & 15.3 & 20.9 & 26.4 & 31.3 & 36.7 & 40.5 & 43.2 & 44.7 \\
\hline 2000 & & 17.6 & 25.2 & 31.3 & 37.1 & 41.5 & 44.6 & 46.5 \\
\hline 2001 & & & 15.3 & 20.8 & 28.0 & 33.5 & 38.6 & 40.7 \\
\hline 2002 & & & & 12.3 & 20.1 & 25.9 & 30.4 & 33.2 \\
\hline 2003 & & & & & 15.1 & 21.9 & 27.0 & 30.0 \\
\hline 2004 & & & & & & 16.8 & 22.5 & 25.6 \\
\hline 2005 & & & & & & & 14.4 & 17.7 \\
\hline 2006 & & & & & & & & 11.5 \\
\hline \multicolumn{9}{|c|}{ D. Percentage Receiving Compensation for Diabetes } \\
\hline 1999 & 0.8 & 1.1 & 2.5 & 7.9 & 11.0 & 12.4 & 13.8 & 14.8 \\
\hline 2000 & & 0.5 & 2.3 & 9.4 & 12.1 & 13.4 & 14.6 & 15.8 \\
\hline 2001 & & & 15.3 & 37.6 & 38.6 & 39.4 & 39.9 & 40.4 \\
\hline 2002 & & & & 58.5 & 59.0 & 59.5 & 59.7 & 59.9 \\
\hline 2003 & & & & & 48.6 & 49.1 & 49.6 & 50.1 \\
\hline 2004 & & & & & & 42.7 & 43.7 & 44.5 \\
\hline 2005 & & & & & & & 39.9 & 40.8 \\
\hline 2006 & & & & & & & & 40.9 \\
\hline
\end{tabular}

Notes: This table reports the progression of Disability Compensation (DC) benefits for veterans in the sample described in the data appendix. Each row corresponds to a DC enrollment cohort. Each column corresponds to a particular year. In panel A, veterans with an IU award are given a CDR of 100. In panel B, mean annual DC payments are in $\$ 2013$. 
Table 2. Distribution of Year of Birth and Start Year in OEMA Sample

\begin{tabular}{|c|c|c|c|c|c|c|c|c|c|}
\hline \multicolumn{5}{|c|}{ A. Year of Birth Distribution } & \multicolumn{5}{|c|}{ B. Start Year Distribution } \\
\hline \multirow[b]{2}{*}{$\begin{array}{l}\text { Birth } \\
\text { Year } \\
(1)\end{array}$} & \multicolumn{2}{|c|}{ NOG Veterans } & \multicolumn{2}{|c|}{ BOG Veterans } & \multirow[b]{2}{*}{$\begin{array}{c}\text { Start Year } \\
(1)\end{array}$} & \multicolumn{2}{|c|}{ NOG Veterans } & \multicolumn{2}{|c|}{ BOG Veterans } \\
\hline & $\begin{array}{c}\text { Observations } \\
(2) \\
\end{array}$ & $\begin{array}{c}\text { Percent of } \\
\text { NOG Sample } \\
(3) \\
\end{array}$ & $\begin{array}{c}\text { Observations } \\
(4) \\
\end{array}$ & $\begin{array}{c}\text { Percent of } \\
\text { BOG Sample } \\
(5) \\
\end{array}$ & & $\begin{array}{c}\text { Observations } \\
(2) \\
\end{array}$ & $\begin{array}{c}\text { Percent of } \\
\text { NOG Sample } \\
(3) \\
\end{array}$ & $\begin{array}{c}\text { Observations } \\
(4)\end{array}$ & $\begin{array}{c}\text { Percent of } \\
\text { BOG Sample } \\
(5) \\
\end{array}$ \\
\hline$\leq 1935$ & 45,287 & 1.75 & 123,079 & 8.26 & $\leq 1955$ & 36,885 & 1.42 & 106,389 & 7.14 \\
\hline 1936 & 2,665 & 0.10 & 13,933 & 0.93 & 1956 & 1,776 & 0.07 & 12,132 & 0.81 \\
\hline 1939 & 4,813 & 0.19 & 15,024 & 1.01 & 1959 & 2,254 & 0.09 & 14,769 & 0.99 \\
\hline 1940 & 7,522 & 0.29 & 17,947 & 1.20 & 1960 & 2,339 & 0.09 & 14,192 & 0.95 \\
\hline 1941 & 10,865 & 0.42 & 23,911 & 1.60 & 1961 & 4,018 & 0.15 & 16,002 & 1.07 \\
\hline 1942 & 18,988 & 0.73 & 34,477 & 2.31 & 1962 & 4,359 & 0.17 & 15,689 & 1.05 \\
\hline 1943 & 29,298 & 1.13 & 47,114 & 3.16 & 1963 & 4,778 & 0.18 & 15,895 & 1.07 \\
\hline 1947 & 108,739 & 4.19 & 227,042 & 15.23 & 1967 & 96,939 & 3.74 & 174,641 & 11.72 \\
\hline 1948 & 165,733 & 6.39 & 227,941 & 15.29 & 1968 & 196,281 & 7.56 & 263,378 & 17.67 \\
\hline 1949 & 155,513 & 5.99 & 191,467 & 12.85 & 1969 & 199,973 & 7.71 & 263,700 & 17.69 \\
\hline 1950 & 143,759 & 5.54 & 134,445 & 9.02 & 1970 & 163,525 & 6.30 & 149,738 & 10.05 \\
\hline 1951 & 141,803 & 5.46 & 72,982 & 4.90 & 1971 & 191,736 & 7.39 & 60,564 & 4.06 \\
\hline 1952 & 165,508 & 6.38 & 37,175 & 2.49 & 1972 & 215,043 & 8.29 & 15,087 & 1.01 \\
\hline 1953 & 141,310 & 5.45 & 15,720 & 1.05 & 1973 & 144,792 & 5.58 & 3,053 & 0.20 \\
\hline 1954 & 157,134 & 6.05 & 5,849 & 0.39 & 1974 & 187,413 & 7.22 & 1,753 & 0.12 \\
\hline 1955 & 162,502 & 6.26 & 919 & 0.06 & 1975 & 162,643 & 6.27 & 1,802 & 0.12 \\
\hline \multirow[t]{2}{*}{$\geq 1956$} & 968,018 & 37.30 & 1,518 & 0.10 & $\geq 1976$ & 920,849 & 35.48 & 3,624 & 0.24 \\
\hline & & & & & Missing & 1,276 & 0.05 & 196,766 & 13.20 \\
\hline
\end{tabular}

Notes: Panel A reports the distribution of birth years in the original OEMA sample for the BOG and NOG subsamples. Panel B reports the distribution of start years. A start year is the year a veteran entered the Army. 
Table 3. Characteristics of the BOG and NOG Samples

\begin{tabular}{|c|c|c|c|c|}
\hline & \multicolumn{2}{|c|}{ A. SSA Verified Sample } & \multicolumn{2}{|c|}{ B. Full Sample } \\
\hline & $\begin{array}{c}\text { BOG } \\
(1)\end{array}$ & $\begin{array}{c}\text { NOG } \\
(2) \\
\end{array}$ & $\begin{array}{c}\text { BOG } \\
(1)\end{array}$ & $\begin{array}{c}\text { NOG } \\
(2) \\
\end{array}$ \\
\hline$\%$ Verified in SSA Data & 100.0 & 100.0 & 95.7 & 89.0 \\
\hline$\%$ with Start Yrs 1966-71 & 100.0 & 100.0 & 100.0 & 100.0 \\
\hline \% with YOB 1946-1951 & 100.0 & 100.0 & 100.0 & 100.0 \\
\hline \% Deceased by 1997 & 4.8 & 2.9 & 6.2 & 6.1 \\
\hline \% Deceased by 2006 & 9.9 & 7.9 & 11.5 & 11.0 \\
\hline$\%$ Nonwhite & 11.3 & 11.8 & 11.8 & 12.7 \\
\hline \% Missing Education & 1.1 & 15.3 & 1.2 & 14.3 \\
\hline \% HS Dropout & 31.4 & 23.3 & 31.4 & 24.3 \\
\hline$\%$ HS Grad & 48.1 & 37.1 & 48.3 & 38.0 \\
\hline$\%$ Some College & 14.5 & 14.4 & 14.3 & 14.2 \\
\hline \% College Grad & 4.8 & 9.2 & 4.7 & 8.6 \\
\hline$\%$ More than College & 0.2 & 0.8 & 0.2 & 0.7 \\
\hline$\%$ Missing AFQT Score & 26.4 & 19.1 & 25.8 & 17.7 \\
\hline Average AFQT Score & 52.1 & 53.4 & 51.7 & 52.5 \\
\hline Average Year of Birth & 1948.4 & 1948.6 & 1948.4 & 1948.7 \\
\hline Average Start Year & 1968.4 & 1969.0 & 1968.4 & 1969.0 \\
\hline Average Loss Year & 1971.1 & 1971.4 & 1971.1 & 1971.4 \\
\hline$\%$ on DC in 1998 & 13.5 & 6.3 & 13.5 & 6.2 \\
\hline$\%$ on $\mathrm{DC}$ in 2000 & 14.3 & 6.5 & 14.2 & 6.4 \\
\hline$\%$ on DC in 2006 & 23.0 & 7.6 & 22.9 & 7.5 \\
\hline Mean Annual DC Payment in 1998 & 10,529 & 9,993 & 10,600 & 10,137 \\
\hline Mean Annual DC Payment in 2000 & 12,078 & 10,750 & 12,140 & 10,888 \\
\hline Mean Annual DC Payment in 2006 & 15,935 & 12,543 & 15,982 & 12,658 \\
\hline Mean Annual DC Pay in 1998 if $>0$ & 10,530 & 9,993 & 10,600 & 10,137 \\
\hline Mean Annual DC Pay in 2000 if $>0$ & 12,079 & 10,751 & 12,140 & 10,889 \\
\hline Mean Annual DC Pay in 2006 if $>0$ & 15,935 & 12,543 & 15,982 & 12,658 \\
\hline \% Positive Earnings in 1998 & 84.3 & 85.1 & & \\
\hline \% Positive Earnings in 2000 & 82.8 & 84.1 & & \\
\hline \% Positive Earnings in 2006 & 71.3 & 74.4 & & \\
\hline Ln(Cell Mean Earnings) in 1998 & 10.67 & 10.70 & & \\
\hline Ln(Cell Mean Earnings) in 2000 & 10.66 & 10.69 & & \\
\hline Ln(Cell Mean Earnings) in 2006 & 10.37 & 10.44 & & \\
\hline$\%$ on SSDI in 1998 & 5.6 & 4.6 & & \\
\hline$\%$ on SSDI in 2000 & 6.8 & 5.5 & & \\
\hline$\%$ on SSDI in 2006 & 12.6 & 9.7 & & \\
\hline \% on SSI in 1998 & 0.7 & 1.0 & & \\
\hline$\%$ on SSI in 2000 & 0.7 & 1.0 & & \\
\hline$\%$ on SSI in 2006 & 0.7 & 1.3 & & \\
\hline Observations & 765,852 & 585,017 & 806,698 & 659,283 \\
\hline
\end{tabular}

Notes: Panel A reports summary statistics for veterans in the BOG and NOG samples described in Section III and the data appendix. Panel B includes veterans who did not verify with the Social Security

Administration, but makes all other sample restrictions described in the data appendix. All earnings and DC payment values are in \$2013. Disability, employment, and earnings information only reflect living veterans. 
Table 4. DC Receipt and Diabetes Compensation among BOG and NOG Veterans, 1998-2006

\begin{tabular}{|c|c|c|c|c|c|c|}
\hline \multirow[b]{2}{*}{ Year } & \multicolumn{2}{|c|}{ Full Sample } & \multicolumn{2}{|c|}{ Whites } & \multicolumn{2}{|c|}{ Nonwhites } \\
\hline & $\begin{array}{c}\text { NOG } \\
(1)\end{array}$ & $\begin{array}{c}\text { BOG } \\
(2) \\
\end{array}$ & $\begin{array}{c}\text { NOG } \\
(3) \\
\end{array}$ & $\begin{array}{c}\text { BOG } \\
(4) \\
\end{array}$ & $\begin{array}{c}\text { NOG } \\
(5) \\
\end{array}$ & $\begin{array}{c}\text { BOG } \\
(6) \\
\end{array}$ \\
\hline \multicolumn{7}{|c|}{ A. Percentage Enrolled in DC } \\
\hline 1998 & 6.3 & 13.5 & 6.0 & 13.0 & 9.0 & 17.1 \\
\hline 1999 & 6.4 & 13.9 & 6.1 & 13.4 & 9.2 & 17.7 \\
\hline 2000 & 6.5 & 14.3 & 6.2 & 13.8 & 9.3 & 18.2 \\
\hline 2001 & 6.6 & 15.0 & 6.3 & 14.4 & 9.4 & 19.3 \\
\hline 2002 & 6.8 & 16.4 & 6.4 & 15.8 & 9.7 & 21.4 \\
\hline 2003 & 7.0 & 18.3 & 6.6 & 17.6 & 10.0 & 24.0 \\
\hline 2004 & 7.2 & 19.9 & 6.8 & 19.1 & 10.3 & 26.0 \\
\hline 2005 & 7.4 & 21.4 & 7.0 & 20.6 & 10.6 & 28.2 \\
\hline 2006 & 7.6 & 23.0 & 7.2 & 22.1 & 10.9 & 30.2 \\
\hline \multicolumn{7}{|c|}{ B. Mean Annual DC Payment, Conditional on DC Enrollment } \\
\hline 1998 & 9,993 & 10,529 & 9,989 & 10,476 & 10,011 & 10,859 \\
\hline 1999 & 10,356 & 11,284 & 10,324 & 11,206 & 10,515 & 11,765 \\
\hline 2000 & 10,750 & 12,078 & 10,690 & 11,987 & 11,055 & 12,635 \\
\hline 2001 & 11,089 & 12,763 & 11,022 & 12,654 & 11,427 & 13,422 \\
\hline 2002 & 11,225 & 13,109 & 11,135 & 12,976 & 11,675 & 13,908 \\
\hline 2003 & 11,665 & 13,992 & 11,537 & 13,835 & 12,310 & 14,923 \\
\hline 2004 & 11,991 & 14,773 & 11,850 & 14,577 & 12,702 & 15,933 \\
\hline 2005 & 12,237 & 15,420 & 12,082 & 15,207 & 13,018 & 16,688 \\
\hline 2006 & 12,543 & 15,935 & 12,381 & 15,696 & 13,363 & 17,358 \\
\hline \multicolumn{7}{|c|}{ C. Percentage Receiving Compensation for Diabetes, Conditional on DC Enrollment } \\
\hline 1998 & & & & & & \\
\hline 1999 & 1.4 & 0.7 & 1.2 & 0.6 & 2.2 & 1.3 \\
\hline 2000 & 1.4 & 0.7 & 1.2 & 0.6 & 2.2 & 1.3 \\
\hline 2001 & 1.6 & 2.4 & 1.4 & 2.2 & 2.5 & 3.9 \\
\hline 2002 & 3.3 & 13.3 & 3.0 & 12.4 & 4.8 & 18.3 \\
\hline 2003 & 4.4 & 19.6 & 4.0 & 18.4 & 6.3 & 26.2 \\
\hline 2004 & 5.2 & 22.9 & 4.8 & 21.8 & 7.2 & 30.0 \\
\hline 2005 & 5.8 & 25.6 & 5.4 & 24.4 & 7.8 & 32.8 \\
\hline 2006 & 6.4 & 28.1 & 6.0 & 26.9 & 8.4 & 35.2 \\
\hline
\end{tabular}

Notes: Panel A of this table reports the percentage of veterans in the BOG and NOG samples who were enrolled in the DC program between 1998 and 2006. Panel B reports the mean monthly disability payments (in \$2013) for veterans who were enrolled in the DC program between 1998 and 2006. Panel C reports the percenage of DC enrolled veterans who received compensation for diabetes. 1998 is not included in panel C because our data include specific conditions for 1999 through 2006 only. 
Table 5. DC Receipt in the BOG versus NOG samples from 1998-2006

Dependent Variable: Percentage of Cell Enrolled in DC

\begin{tabular}{|c|c|c|c|c|c|c|}
\hline & \multicolumn{2}{|c|}{ A. All } & \multicolumn{2}{|c|}{ B. YOB: 1946-1948 } & \multicolumn{2}{|c|}{ C. YOB: 1949-1951 } \\
\hline & (1) & (2) & $(1)$ & $(2)$ & $(1)$ & $(2)$ \\
\hline BOG & $\begin{array}{l}6.97 * * * \\
(0.06)\end{array}$ & $\begin{array}{l}6.91 * * * \\
(0.05)\end{array}$ & $\begin{array}{l}7.12 * * * \\
(0.09)\end{array}$ & $\begin{array}{l}7.06^{* * *} \\
(0.07)\end{array}$ & $\begin{array}{l}6.83^{* * *} \\
(0.09)\end{array}$ & $\begin{array}{l}6.77 * * * \\
(0.07)\end{array}$ \\
\hline BOG * (YR-1998) & & $\begin{array}{l}0.40^{* * *} \\
(0.02)\end{array}$ & & $\begin{array}{l}0.40^{* * *} \\
(0.03)\end{array}$ & & $\begin{array}{l}0.40^{* * *} \\
(0.03)\end{array}$ \\
\hline $\begin{array}{l}\mathrm{BOG} *(\mathrm{YR}-2001) * \\
(\mathrm{YR} \geq 2002)\end{array}$ & & $\begin{array}{l}0.99 * * * \\
(0.03)\end{array}$ & & $\begin{array}{l}1.04^{* * *} \\
(0.05)\end{array}$ & & $\begin{array}{l}0.93 * * * \\
(0.05)\end{array}$ \\
\hline BOG * (YR99) & $\begin{array}{l}0.33 * * * \\
(0.09)\end{array}$ & & $\begin{array}{l}0.34 * * * \\
(0.13)\end{array}$ & & $\begin{array}{l}0.32^{* *} \\
(0.12)\end{array}$ & \\
\hline BOG * (YR00) & $\begin{array}{l}0.59 * * * \\
(0.09)\end{array}$ & & $\begin{array}{l}0.58^{* * *} \\
(0.13)\end{array}$ & & $\begin{array}{l}0.61 * * * \\
(0.12)\end{array}$ & \\
\hline BOG *(YR01) & $\begin{array}{l}1.18^{* * *} \\
(0.09)\end{array}$ & & $\begin{array}{l}1.18^{* * *} \\
(0.13)\end{array}$ & & $\begin{array}{l}1.18^{* * *} \\
(0.12)\end{array}$ & \\
\hline BOG * (YR02) & $\begin{array}{l}2.46^{* * *} \\
(0.09)\end{array}$ & & $\begin{array}{l}2.55^{* * *} \\
(0.13)\end{array}$ & & $\begin{array}{l}2.37 * * * \\
(0.12)\end{array}$ & \\
\hline BOG *(YR03) & $\begin{array}{l}4.08^{* * *} \\
(0.09)\end{array}$ & & $\begin{array}{l}4.22 * * * \\
(0.13)\end{array}$ & & $\begin{array}{l}3.92 * * * \\
(0.12)\end{array}$ & \\
\hline BOG *(YR04) & $\begin{array}{l}5.39 * * * \\
(0.09)\end{array}$ & & $\begin{array}{l}5.58 * * * \\
(0.13)\end{array}$ & & $\begin{array}{l}5.18^{* * *} \\
(0.12)\end{array}$ & \\
\hline BOG *(YR05) & $\begin{array}{l}6.71 * * * \\
(0.09)\end{array}$ & & $\begin{array}{l}6.93 * * * \\
(0.13)\end{array}$ & & $\begin{array}{l}6.45^{* * *} \\
(0.12)\end{array}$ & \\
\hline BOG * (YR06) & $\begin{array}{l}7.98 * * * \\
(0.09)\end{array}$ & & $\begin{array}{l}8.28 * * * \\
(0.13)\end{array}$ & & $\begin{array}{l}7.65 * * * \\
(0.13)\end{array}$ & \\
\hline $\begin{array}{l}\text { Outcome Mean (1998) } \\
\text { \# OBS (Cell)x(Year) }\end{array}$ & $\begin{array}{r}10 . \\
2,142\end{array}$ & & $\begin{array}{r}10 \\
1,10\end{array}$ & & $\begin{array}{r}9.5 \\
1,037\end{array}$ & \\
\hline
\end{tabular}

Notes: This table reports estimates of equations (1) and (2) where the dependent variable is the percentage of each cell enrolled in the Disability Compensation program each year. Panel A includes all veterans in our sample and other panels restrict the sample to veterans in the specified group. Each cell has one observation for each year between 1998 and 2006. All regressions include year fixed effects and fixed effects for each combationation of (AFQT-

quintile)x(year), (year of birth)x(year), and (race)x(year), where race is defined as white or nonwhite and veterans with a missing AFQT score are grouped into a sixth AFQT category. All regressions weight each observation according to the number of veterans in the cell. Standard errors are reported in parentheses. ${ }^{* *}, *^{*}$, and $*$ denote significance at the $1 \%, 5 \%$, and $10 \%$ level, respectively. 
Table 6. Disability Compensation Outcomes in the BOG versus NOG samples from 1998-2006

\begin{tabular}{|c|c|c|c|c|c|}
\hline & $\begin{array}{l}\text { All } \\
(1) \\
\end{array}$ & $\begin{array}{c}\text { Nonwhites } \\
(2) \\
\end{array}$ & $\begin{array}{c}\text { Whites } \\
(3) \\
\end{array}$ & $\begin{array}{c}\text { AFQT }<45 \\
(4) \\
\end{array}$ & $\begin{array}{c}\text { AFQT } \geq 45 \\
(5) \\
\end{array}$ \\
\hline \multicolumn{6}{|c|}{ A. Dependent Variable: Percentage of Cell enrolled in DC } \\
\hline BOG & $\begin{array}{l}6.91 * * * \\
(0.05)\end{array}$ & $\begin{array}{l}7.72 * * * \\
(0.17)\end{array}$ & $\begin{array}{l}6.80^{* * *} \\
(0.05)\end{array}$ & $\begin{array}{l}8.33^{* * *} \\
(0.10)\end{array}$ & $\begin{array}{l}5.93 * * * \\
(0.07)\end{array}$ \\
\hline $\mathrm{BOG} *(\mathrm{YR}-1998)$ & $\begin{array}{l}0.40 * * * \\
(0.02)\end{array}$ & $\begin{array}{l}0.61 * * * \\
(0.08)\end{array}$ & $\begin{array}{l}0.37 * * * \\
(0.03)\end{array}$ & $\begin{array}{l}0.52 * * * \\
(0.05)\end{array}$ & $\begin{array}{l}0.31 * * * \\
(0.03)\end{array}$ \\
\hline $\begin{array}{l}\mathrm{BOG} *(\mathrm{YR}-2001) * \\
(\mathrm{YR} \geq 2002)\end{array}$ & $\begin{array}{l}0.99 * * * \\
(0.03)\end{array}$ & $\begin{array}{l}1.27 * * * \\
(0.11)\end{array}$ & $\begin{array}{l}0.95 * * * \\
(0.04)\end{array}$ & $\begin{array}{l}1.19 * * * \\
(0.06)\end{array}$ & $\begin{array}{l}0.81 * * * \\
(0.05)\end{array}$ \\
\hline $\begin{array}{l}\text { Outcome Mean (1998) } \\
\text { \# OBS (Cell)x(Year) }\end{array}$ & $\begin{array}{c}10.36 \\
2,142,029\end{array}$ & $\begin{array}{c}13.44 \\
232,540\end{array}$ & $\begin{array}{c}9.96 \\
1,909,489\end{array}$ & $\begin{array}{c}11.55 \\
660,866\end{array}$ & $\begin{array}{c}8.98 \\
988,801\end{array}$ \\
\hline \multicolumn{6}{|c|}{ B. Dependent Variable: Cell Mean Combined Disability Rating (CDR) } \\
\hline BOG & $\begin{array}{l}2.88^{* * *} \\
(0.03)\end{array}$ & $\begin{array}{l}3.39 * * * \\
(0.10)\end{array}$ & $\begin{array}{l}2.81 * * * \\
(0.03)\end{array}$ & $\begin{array}{l}3.83 * * * \\
(0.06)\end{array}$ & $\begin{array}{l}2.48 * * * \\
(0.04)\end{array}$ \\
\hline $\mathrm{BOG} *(\mathrm{YR}-1998)$ & $\begin{array}{l}0.34 * * * \\
(0.01)\end{array}$ & $\begin{array}{l}0.50 * * * \\
(0.05)\end{array}$ & $\begin{array}{l}0.32^{* * * *} \\
(0.01)\end{array}$ & $\begin{array}{l}0.47^{* * *} \\
(0.03)\end{array}$ & $\begin{array}{l}0.26 * * * \\
(0.02)\end{array}$ \\
\hline $\begin{array}{l}\mathrm{BOG} *(\mathrm{YR}-2001) * \\
(\mathrm{YR} \geq 2002)\end{array}$ & $\begin{array}{l}0.66^{* * *} \\
(0.02)\end{array}$ & $\begin{array}{l}0.96^{* * *} \\
(0.07)\end{array}$ & $\begin{array}{l}0.63 * * * \\
(0.02)\end{array}$ & $\begin{array}{l}0.83^{* * *} \\
(0.04)\end{array}$ & $\begin{array}{l}0.51 * * * \\
(0.03)\end{array}$ \\
\hline $\begin{array}{l}\text { Outcome Mean (1998) } \\
\text { \# OBS (Cell)x(Year) }\end{array}$ & $\begin{array}{c}3.96 \\
2,142,029\end{array}$ & $\begin{array}{c}5.25 \\
232,540\end{array}$ & $\begin{array}{c}3.79 \\
1,909,489\end{array}$ & $\begin{array}{c}4.75 \\
660,866\end{array}$ & $\begin{array}{c}3.19 \\
988,801\end{array}$ \\
\hline \multicolumn{6}{|c|}{ C. Dependent Variable: Cell Mean Annual DC Payment } \\
\hline BOG & $\begin{array}{l}766^{* * *} \\
(10)\end{array}$ & $\begin{array}{l}930 * * * \\
(35)\end{array}$ & $\begin{array}{l}744 * * * \\
(11)\end{array}$ & $\begin{array}{l}1,072 * * * \\
(20)\end{array}$ & $\begin{array}{l}673 * * * \\
(13)\end{array}$ \\
\hline $\mathrm{BOG} *(\mathrm{YR}-1998)$ & $\begin{array}{l}113 * * * \\
(5)\end{array}$ & $\begin{array}{l}159^{* * * *} \\
(17)\end{array}$ & $\begin{array}{l}107 * * * \\
(5)\end{array}$ & $\begin{array}{l}158 * * * \\
(10)\end{array}$ & $\begin{array}{l}85 * * * \\
(6)\end{array}$ \\
\hline $\begin{array}{l}\mathrm{BOG} *(\mathrm{YR}-2001) * \\
(\mathrm{YR} \geq 2002)\end{array}$ & $\begin{array}{l}192 * * * \\
(7)\end{array}$ & $\begin{array}{l}290 * * * \\
(24)\end{array}$ & $\begin{array}{l}179^{* * * *} \\
(7)\end{array}$ & $\begin{array}{l}239 * * * \\
(14)\end{array}$ & $\begin{array}{l}145^{* * * *} \\
(9)\end{array}$ \\
\hline $\begin{array}{l}\text { Outcome Mean (1998) } \\
\text { \# OBS (Cell)x(Year) }\end{array}$ & $\begin{array}{c}1,076 \\
2,142,029\end{array}$ & $\begin{array}{c}1,425 \\
232,540\end{array}$ & $\begin{array}{c}1,031 \\
1,909,489\end{array}$ & $\begin{array}{c}1,323 \\
660,866\end{array}$ & $\begin{array}{c}851 \\
988,801\end{array}$ \\
\hline
\end{tabular}

Notes: This table reports estimates of equation (2) where the dependent variable is the outcome indicated in the panel heading. Each cell has one observation for each year between 1998 and 2006. All regressions include year fixed effects and fixed effects for each combationation of (AFQT-quintile)x(year), (year of birth) $\mathrm{x}(\mathrm{year})$, and (race) $\mathrm{x}(\mathrm{year})$, where race is defined as white or nonwhite. Column 1 includes all veterans in our sample; all other columns restrict the sample to veterans in the specified group. Columns 1-3 group veterans with a missing AFQT score into a sixth AFQT category while columns 4-5 exclude veterans with missing AFQT scores. In panel B, veterans with an IU rating are coded as having a Combined Disability Rating (CDR) of 100. In panel C, mean annual DC payments are in \$2013. All regressions weight each observation according to the number of veterans in the cell. Standard errors are reported in parentheses. ${ }^{* *}, * *$, and $*$ denote significance at the $1 \%, 5 \%$, and $10 \%$ level, respectively. 
Table 7. SSDI, SSI, and Total Disability Income in the BOG versus NOG samples

\begin{tabular}{|c|c|c|c|c|c|}
\hline & $\begin{array}{l}\text { All } \\
(1) \\
\end{array}$ & $\begin{array}{c}\text { Nonwhites } \\
(2) \\
\end{array}$ & $\begin{array}{l}\text { Whites } \\
(3) \\
\end{array}$ & $\begin{array}{c}\text { AFQT }<45 \\
(4) \\
\end{array}$ & $\begin{array}{c}\text { AFQT } \geq 45 \\
(5) \\
\end{array}$ \\
\hline \multicolumn{6}{|c|}{ A. Dependent Variable: Percentage of Cell Receiving SSDI } \\
\hline BOG & $\begin{array}{l}0.74 * * * \\
(0.04)\end{array}$ & $\begin{array}{l}1.14^{* * *} \\
(0.12)\end{array}$ & $\begin{array}{l}0.69^{* * *} \\
(0.04)\end{array}$ & $\begin{array}{l}1.12 * * * \\
(0.07)\end{array}$ & $\begin{array}{l}0.81 * * * \\
(0.04)\end{array}$ \\
\hline BOG * (YR-1996) & $\begin{array}{l}0.13^{* * *} \\
(0.01)\end{array}$ & $\begin{array}{l}0.19 * * * \\
(0.04)\end{array}$ & $\begin{array}{l}0.13 * * * \\
(0.01)\end{array}$ & $\begin{array}{l}0.14 * * * \\
(0.02)\end{array}$ & $\begin{array}{l}0.11^{* * *} \\
(0.01)\end{array}$ \\
\hline $\begin{array}{l}\mathrm{BOG} *(\mathrm{YR}-2001) * \\
(\mathrm{YR} \geq 2002)\end{array}$ & $\begin{array}{l}0.12 * * * \\
(0.02)\end{array}$ & $\begin{array}{c}0.06 \\
(0.06)\end{array}$ & $\begin{array}{l}0.12 * * * \\
(0.02)\end{array}$ & $\begin{array}{l}0.12 * * * \\
(0.04)\end{array}$ & $\begin{array}{l}0.10 * * * \\
(0.02)\end{array}$ \\
\hline $\begin{array}{l}\text { Outcome Mean (1996) } \\
\text { \# OBS (Cell)x(Year) }\end{array}$ & $\begin{array}{c}4.51 \\
2,862,513\end{array}$ & $\begin{array}{c}6.69 \\
310,987\end{array}$ & $\begin{array}{c}4.23 \\
2,551,526\end{array}$ & $\begin{array}{c}6.77 \\
883,832\end{array}$ & $\begin{array}{c}3.08 \\
1,321,309\end{array}$ \\
\hline \multicolumn{6}{|c|}{ B. Dependent Variable: Percentage of Cell Receiving SSI } \\
\hline BOG & $\begin{array}{l}-0.238^{* * * *} \\
(0.012)\end{array}$ & $\begin{array}{l}-0.353^{* * *} \\
(0.055)\end{array}$ & $\begin{array}{l}-0.222 * * * \\
(0.012)\end{array}$ & $\begin{array}{l}-0.328^{* * *} \\
(0.028)\end{array}$ & $\begin{array}{l}-0.063 * * * \\
(0.013)\end{array}$ \\
\hline BOG * (YR-1996) & $\begin{array}{l}-0.025 * * * \\
(0.004)\end{array}$ & $\begin{array}{l}-0.024 \\
(0.016)\end{array}$ & $\begin{array}{l}-0.025^{* * * *} \\
(0.003)\end{array}$ & $\begin{array}{l}-0.038 * * * \\
(0.008)\end{array}$ & $\begin{array}{l}-0.015^{* * *} \\
(0.004)\end{array}$ \\
\hline $\begin{array}{l}\mathrm{BOG} *(\mathrm{YR}-2001) * \\
(\mathrm{YR} \geq 2002)\end{array}$ & $\begin{array}{l}-0.013 * * \\
(0.006)\end{array}$ & $\begin{array}{l}-0.052 * * \\
(0.026)\end{array}$ & $\begin{array}{l}-0.008 \\
(0.006)\end{array}$ & $\begin{array}{l}-0.036^{* * *} \\
(0.013)\end{array}$ & $\begin{array}{l}-0.004 \\
(0.006)\end{array}$ \\
\hline $\begin{array}{l}\text { Outcome Mean (1996) } \\
\text { \# OBS (Cell)x(Year) }\end{array}$ & $\begin{array}{c}0.90 \\
2,862,513\end{array}$ & $\begin{array}{c}2.26 \\
310,987\end{array}$ & $\begin{array}{c}0.73 \\
2,551,526\end{array}$ & $\begin{array}{c}1.54 \\
883,832\end{array}$ & $\begin{array}{c}0.50 \\
1,321,309\end{array}$ \\
\hline \multicolumn{6}{|c|}{ C. Dependent Variable: Annual Disability Income (DC Ben + SSDI Ben + SSI Ben), 1998-2006 only } \\
\hline BOG & $\begin{array}{l}861^{* * *} \\
(13)\end{array}$ & $\begin{array}{l}1,061^{* * *} \\
(44)\end{array}$ & $\begin{array}{l}835^{* * *} \\
(14)\end{array}$ & $\begin{array}{l}1,197^{* * *} \\
(26)\end{array}$ & $\begin{array}{l}772 * * * \\
(17)\end{array}$ \\
\hline BOG * (YR-1998) & $\begin{array}{l}128 * * * \\
(6)\end{array}$ & $\begin{array}{l}178^{* * * *} \\
(21)\end{array}$ & $\begin{array}{l}121 * * * \\
(6)\end{array}$ & $\begin{array}{l}172^{* * *} \\
(12)\end{array}$ & $\begin{array}{l}98 * * * \\
(8)\end{array}$ \\
\hline $\begin{array}{l}\mathrm{BOG} *(\mathrm{YR}-2001) * \\
(\mathrm{YR} \geq 2002)\end{array}$ & $\begin{array}{l}226 * * * \\
(9)\end{array}$ & $\begin{array}{l}325^{* * *} \\
(30)\end{array}$ & $\begin{array}{l}214 * * * \\
(9)\end{array}$ & $\begin{array}{l}277 * * * \\
(18)\end{array}$ & $\begin{array}{l}173^{* * *} \\
(11)\end{array}$ \\
\hline Outcome Mean (1998) & 1,608 & 2,181 & 1,535 & 2,093 & 1,225 \\
\hline Total Income Mean (1998) & 53,639 & 38,276 & 55,601 & 39,549 & 59,663 \\
\hline \# OBS (Cell)x(Year) & $2,142,029$ & 232,540 & $1,909,489$ & 660,866 & 988,801 \\
\hline
\end{tabular}

Notes: This table reports estimates of equation (2) where the dependent variable is the outcome indicated in each panel heading. In panels A and B, each cell has one observation for each year between 1996 and 2007. Panel C only includes observations from 1998 through 2006 since DC outcomes are not available in other years. Annual disability benefits in panel $\mathrm{C}$ are in \$2013. All regressions include year fixed effects and fixed effects for each combationation of (AFQT-quintile)x(year), (year of birth)x(year), and (race)x(year), where race is defined as white or nonwhite. Column 1 includes all veterans in our sample and columns 2-5 restrict the sample to veterans in the specified group. Columns 1-3 group veterans with a missing AFQT score into a sixth AFQT category while columns 4-5 exclude veterans with missing AFQT scores. All regressions weight each observation according to the number of veterans in the cell. Standard errors are reported in parentheses. $* * *, * *$, and $*$ denote significance at the $1 \%, 5 \%$, and $10 \%$ level, respectively. 
Table 8. Labor Force Participation in the BOG versus NOG samples from 1996-2007

Dependent Variable: Percentage of Cell with Positive Annual Earnings

\begin{tabular}{|c|c|c|c|c|c|c|}
\hline & \multicolumn{2}{|c|}{ A. All } & \multicolumn{2}{|c|}{ B. YOB: 1946-1948 } & \multicolumn{2}{|c|}{ C. YOB: $1949-1951$} \\
\hline & $(1)$ & $(2)$ & $(1)$ & $(2)$ & (1) & $(2)$ \\
\hline \multirow[t]{2}{*}{ BOG } & $-0.32 * * *$ & $-0.33 * * *$ & 0.00 & 0.02 & $-0.82 * * *$ & $-0.87 * * *$ \\
\hline & $(0.08)$ & $(0.05)$ & $(0.10)$ & $(0.07)$ & $(0.11)$ & $(0.08)$ \\
\hline \multirow[t]{2}{*}{ BOG * (YR-1996) } & & $-0.15 * * *$ & & $-0.17 * * *$ & & $-0.14 * * *$ \\
\hline & & $(0.02)$ & & $(0.02)$ & & $(0.02)$ \\
\hline BOG * (YR-2001) * & & $-0.18 * * *$ & & $-0.19 * * *$ & & $-0.18 * * *$ \\
\hline$(Y R \geq 2002)$ & & $(0.03)$ & & $(0.04)$ & & $(0.04)$ \\
\hline \multirow[t]{2}{*}{ BOG * (YR97) } & -0.16 & & -0.15 & & -0.16 & \\
\hline & $(0.11)$ & & $(0.15)$ & & $(0.16)$ & \\
\hline \multirow[t]{2}{*}{ BOG * (YR98) } & $-0.31 * * *$ & & $-0.29 * *$ & & $-0.33 * *$ & \\
\hline & $(0.11)$ & & $(0.15)$ & & $(0.16)$ & \\
\hline \multirow[t]{2}{*}{ BOG * (YR99) } & $-0.45 * * *$ & & $-0.38 * *$ & & $-0.52 * * *$ & \\
\hline & $(0.11)$ & & $(0.15)$ & & $(0.16)$ & \\
\hline \multirow[t]{2}{*}{ BOG * (YR00) } & $-0.77 * * *$ & & $-0.79 * * *$ & & $-0.75^{* * *}$ & \\
\hline & $(0.11)$ & & $(0.15)$ & & $(0.16)$ & \\
\hline \multirow[t]{2}{*}{ BOG * (YR01) } & $-0.81 * * *$ & & $-0.87 * * *$ & & $-0.76^{* * *}$ & \\
\hline & $(0.11)$ & & $(0.15)$ & & $(0.16)$ & \\
\hline \multirow[t]{2}{*}{$\mathrm{BOG} *(\mathrm{YR} 02)$} & $-1.01 * * *$ & & $-1.06^{* * *}$ & & $-0.96 * * *$ & \\
\hline & $(0.11)$ & & $(0.15)$ & & $(0.16)$ & \\
\hline \multirow[t]{2}{*}{ BOG *(YR03) } & $-1.34 * * *$ & & $-1.45^{* * *}$ & & $-1.23^{* * *}$ & \\
\hline & $(0.11)$ & & $(0.15)$ & & $(0.16)$ & \\
\hline \multirow[t]{2}{*}{ BOG *(YR04) } & $-1.74 * * *$ & & $-1.92 * * *$ & & $-1.55^{* * *}$ & \\
\hline & $(0.11)$ & & $(0.15)$ & & $(0.16)$ & \\
\hline \multirow[t]{2}{*}{ BOG *(YR05) } & $-2.15 * * *$ & & $-2.27 * * *$ & & $-2.03 * * *$ & \\
\hline & $(0.11)$ & & $(0.15)$ & & $(0.16)$ & \\
\hline \multirow[t]{2}{*}{$\mathrm{BOG} *(\mathrm{YR} 06)$} & $-2.43 * * *$ & & $-2.56^{* * *}$ & & $-2.29 * * *$ & \\
\hline & $(0.11)$ & & $(0.15)$ & & $(0.16)$ & \\
\hline \multirow[t]{2}{*}{ BOG *(YR07) } & $-2.83 * * *$ & & $-2.93 * * *$ & & $-2.73 * * *$ & \\
\hline & $(0.11)$ & & $(0.15)$ & & $(0.16)$ & \\
\hline Outcome Mean (1996) & \multicolumn{2}{|c|}{85.70} & \multicolumn{2}{|c|}{86.56} & \multicolumn{2}{|c|}{84.80} \\
\hline \# OBS (Cell)x(Year) & \multicolumn{2}{|c|}{$2,862,513$} & \multicolumn{2}{|c|}{$1,476,423$} & \multicolumn{2}{|c|}{$1,386,090$} \\
\hline
\end{tabular}

Notes: This table reports estimates of equations (1) and (2) where the dependent variable is the percentage of each cell with positive annual earnings. Panel A includes all veterans in our sample and panels B and C restrict the sample to veterans in the specified group. All regressions include year fixed effects and fixed effects for each combationation of (AFQT-quintile)x(year), (year of birth)x(year), and (race)x(year), where race is defined as white or nonwhite and veterans with a missing AFQT score are grouped into a sixth AFQT category. All regressions weight each observation according to the number of veterans in the cell. Standard errors are reported in parentheses. ${ }^{* *}, * *$, and $*$ denote significance at the $1 \%, 5 \%$, and $10 \%$ level, respectively. 
Table 9. LFP and Earnings in the BOG versus NOG samples from 1996-2007

\begin{tabular}{|c|c|c|c|c|c|}
\hline & $\begin{array}{l}\text { All } \\
(1)\end{array}$ & $\begin{array}{c}\text { Nonwhites } \\
(2) \\
\end{array}$ & $\begin{array}{l}\text { Whites } \\
\text { (3) }\end{array}$ & $\begin{array}{c}\text { AFQT }<45 \\
(4) \\
\end{array}$ & $\begin{array}{c}\text { AFQT } \geq 45 \\
(5) \\
\end{array}$ \\
\hline \multicolumn{6}{|c|}{ A. Dependent Variable: Percentage of Cell with Earnings $>0$} \\
\hline BOG & $\begin{array}{l}-0.33 * * * \\
(0.05)\end{array}$ & $\begin{array}{l}-2.50 * * * \\
(0.18)\end{array}$ & $\begin{array}{l}-0.05 \\
(0.06)\end{array}$ & $\begin{array}{l}-0.88^{* * *} \\
(0.10)\end{array}$ & $\begin{array}{l}-0.92 * * * \\
(0.07)\end{array}$ \\
\hline $\mathrm{BOG} *(\mathrm{YR}-1996)$ & $\begin{array}{l}-0.15 * * * \\
(0.02)\end{array}$ & $\begin{array}{l}-0.19 * * * \\
(0.05)\end{array}$ & $\begin{array}{l}-0.15^{* * * *} \\
(0.02)\end{array}$ & $\begin{array}{l}-0.16^{* * *} \\
(0.03)\end{array}$ & $\begin{array}{l}-0.11 * * * \\
(0.02)\end{array}$ \\
\hline $\begin{array}{l}\mathrm{BOG} *(\mathrm{YR}-2001) * \\
(\mathrm{YR} \geq 2002)\end{array}$ & $\begin{array}{l}-0.18 * * * \\
(0.03)\end{array}$ & $\begin{array}{l}-0.22^{* *} \\
(0.09)\end{array}$ & $\begin{array}{l}-0.18 * * * \\
(0.03)\end{array}$ & $\begin{array}{l}-0.20 * * * \\
(0.05)\end{array}$ & $\begin{array}{l}-0.15 * * * \\
(0.03)\end{array}$ \\
\hline $\begin{array}{l}\text { Outcome Mean (1996) } \\
\text { \# OBS (Cell)x(Year) }\end{array}$ & $\begin{array}{c}85.70 \\
2,862,513\end{array}$ & $\begin{array}{c}78.18 \\
310,987\end{array}$ & $\begin{array}{c}86.67 \\
2,551,526\end{array}$ & $\begin{array}{c}81.70 \\
883,832\end{array}$ & $\begin{array}{c}89.08 \\
1,321,309\end{array}$ \\
\hline \multicolumn{6}{|c|}{ B. Dependent Variable: 100 x Ln(Cell Mean Earnings) } \\
\hline BOG & $\begin{array}{l}-2.59 * * * \\
(0.18)\end{array}$ & $\begin{array}{l}-4.68 * * * \\
(0.62)\end{array}$ & $\begin{array}{l}-2.30 * * * \\
(0.18)\end{array}$ & $\begin{array}{c}0.02 \\
(0.32)\end{array}$ & $\begin{array}{l}-4.10 * * * \\
(0.23)\end{array}$ \\
\hline $\mathrm{BOG} *(\mathrm{YR}-1996)$ & $\begin{array}{l}-0.23 * * * \\
(0.05)\end{array}$ & $\begin{array}{l}-0.33^{*} \\
(0.18)\end{array}$ & $\begin{array}{l}-0.21 * * * \\
(0.05)\end{array}$ & $\begin{array}{l}-0.27 * * * \\
(0.10)\end{array}$ & $\begin{array}{l}-0.13^{*} \\
(0.07)\end{array}$ \\
\hline $\begin{array}{l}\mathrm{BOG} *(\mathrm{YR}-2001) * \\
(\mathrm{YR} \geq 2002)\end{array}$ & $\begin{array}{l}-0.45^{* * *} \\
(0.08)\end{array}$ & $\begin{array}{l}-0.77 * * * \\
(0.30)\end{array}$ & $\begin{array}{l}-0.41 * * * \\
(0.09)\end{array}$ & $\begin{array}{l}-0.40^{* *} \\
(0.16)\end{array}$ & $\begin{array}{l}-0.27 * * \\
(0.11)\end{array}$ \\
\hline Outcome Mean (1996) & $1,065.83$ & $1,032.25$ & $1,070.12$ & $1,038.31$ & $1,080.45$ \\
\hline Earnings Mean (1996) & 49,848 & 35,449 & 51,691 & 36,656 & 55,709 \\
\hline \# OBS (Cell)x(Year) & $2,855,305$ & 308,923 & $2,546,382$ & 879,962 & $1,320,155$ \\
\hline \multicolumn{6}{|c|}{ C. Dependent Variable: 100 x Ln(Percentage of Cell with Earnings $>0)$} \\
\hline BOG & $\begin{array}{l}-0.29 * * * \\
(0.08)\end{array}$ & $\begin{array}{l}-3.57 * * * \\
(0.31)\end{array}$ & $\begin{array}{c}0.13 \\
(0.09)\end{array}$ & $\begin{array}{l}-1.20^{* * *} \\
(0.17)\end{array}$ & $\begin{array}{l}-1.14 * * * \\
(0.10)\end{array}$ \\
\hline BOG * (YR-1996) & $\begin{array}{l}-0.21 * * * \\
(0.02)\end{array}$ & $\begin{array}{l}-0.31 * * * \\
(0.09)\end{array}$ & $\begin{array}{l}-0.20 * * * \\
(0.03)\end{array}$ & $\begin{array}{l}-0.24^{* * *} \\
(0.05)\end{array}$ & $\begin{array}{l}-0.16 * * * \\
(0.03)\end{array}$ \\
\hline $\begin{array}{l}\mathrm{BOG} *(\mathrm{YR}-2001) * \\
(\mathrm{YR} \geq 2002)\end{array}$ & $\begin{array}{l}-0.36 * * * \\
(0.04)\end{array}$ & $\begin{array}{l}-0.52^{* * *} \\
(0.15)\end{array}$ & $\begin{array}{l}-0.35 * * * \\
(0.04)\end{array}$ & $\begin{array}{l}-0.44 * * * \\
(0.08)\end{array}$ & $\begin{array}{l}-0.29 * * * \\
(0.05)\end{array}$ \\
\hline Outcome Mean (1996) & -17.85 & -28.26 & -16.51 & -23.28 & -13.25 \\
\hline \# OBS (Cell)x(Year) & $2,855,305$ & 308,923 & $2,546,382$ & 879,962 & $1,320,155$ \\
\hline
\end{tabular}

Notes: This table reports estimates of equation (2) where the dependent variable is the outcome indicated in each panel heading. Each cell has one observation for each year between 1996 and 2007. Panels B and C exclude cells with 0 mean annual earnings. All earnings outcomes are in \$2013. All regressions include year fixed effects and fixed effects for each combationation of (AFQT-quintile)x(year), (year of birth)x(year), and (race)x(year), where race is defined as white or nonwhite. Column 1 includes all veterans in our sample and columns 2-5 restrict the sample to veterans in the specified group. Columns 1-3 group veterans with a missing AFQT score into a sixth AFQT category while columns 4-5 exclude veterans with missing AFQT scores. All regressions weight each observation according to the number of veterans in the cell. Standard errors are reported in parentheses. $* * *, * *$, and $*$ denote significance at the $1 \%, 5 \%$, and $10 \%$ level, respectively. 
Table 10. 2SLS Estimates of DC Receipt and Annual Disability Benefits on Labor Force Participation

Dependent Variable: Percentage of Cell with Positive Earnings. 1998-2006.

\begin{tabular}{|c|c|c|c|c|c|c|c|}
\hline & $\begin{array}{l}\text { All } \\
(1) \\
\end{array}$ & $\begin{array}{c}\text { YOB: } 1946- \\
1948 \\
(2) \\
\end{array}$ & $\begin{array}{c}\text { YOB: 1949- } \\
1951 \\
(3) \\
\end{array}$ & $\begin{array}{c}\text { Nonwhites } \\
(4) \\
\end{array}$ & $\begin{array}{c}\text { Whites } \\
(5) \\
\end{array}$ & $\begin{array}{c}\text { AFQT }<45 \\
(6) \\
\end{array}$ & $\begin{array}{c}\text { AFQT } \geq 45 \\
(7) \\
\end{array}$ \\
\hline \multicolumn{8}{|c|}{ A. Endogenous Variable: Percentage of Cell Enrolled in DC } \\
\hline DC Enrollment & $\begin{array}{l}-0.18 * * * \\
(0.04)\end{array}$ & $\begin{array}{l}-0.16^{* * * *} \\
(0.06)\end{array}$ & $\begin{array}{l}-0.21 \text { *** } \\
(0.07)\end{array}$ & $\begin{array}{l}-0.25^{* *} \\
(0.11)\end{array}$ & $\begin{array}{l}-0.17^{* * *} \\
(0.05)\end{array}$ & $\begin{array}{l}-0.20 * * * \\
(0.07)\end{array}$ & $\begin{array}{l}-0.17 * * \\
(0.07)\end{array}$ \\
\hline Outcome Mean (1998) & 84.7 & 85.5 & 83.9 & 77.1 & 85.7 & 80.5 & 88.3 \\
\hline \# OBS (Cell)x(Year) & $2,142,029$ & $1,104,897$ & $1,037,132$ & 232,540 & $1,909,489$ & 660,866 & 988,801 \\
\hline \multicolumn{8}{|c|}{ B. Endogenous Variable: (DC Benefits + SSDI Benefits + SSI Benefits)/1000 } \\
\hline (Disability Benefits)/1000 & $\begin{array}{l}-0.80 * * * \\
(0.18)\end{array}$ & $\begin{array}{l}-0.70 * * * \\
(0.23)\end{array}$ & $\begin{array}{l}-0.94 * * * \\
(0.28)\end{array}$ & $\begin{array}{l}-0.97 * * \\
(0.42)\end{array}$ & $\begin{array}{l}-0.77 * * * \\
(0.19)\end{array}$ & $\begin{array}{l}-0.84 * * * \\
(0.28)\end{array}$ & $\begin{array}{l}-0.82 * * * \\
(0.31)\end{array}$ \\
\hline Outcome Mean (1998) & 84.7 & 85.5 & 83.9 & 77.1 & 85.7 & 80.5 & 88.3 \\
\hline \# OBS (Cell)x(Year) & $2,142,029$ & $1,104,897$ & $1,037,132$ & 232,540 & $1,909,489$ & 660,866 & 988,801 \\
\hline
\end{tabular}

Notes: This table reports 2SLS estimates of the effects of DC receipt on labor force participation (panel A) and annual disability benefits on labor force participation (panel B). The instrument for all estimates is (BOG)x(year - 2001)x1(year $\geq 2002)$. All regressions include a main effect for (BOG), a (BOG)x(year - 1998) time trend, year fixed effects, and fixed effects for each combationation of (AFQT-quintile)x(year), (year of birth)x(year), and (race)x(year). Annual disability benefits are in \$2013. Each cell has one observation for each year between 1998 and 2006 and all regressions weight each observation according to the number of veterans in the cell. Standard errors are reported in parentheses. $* * * * *$, and $*$ denote significance at the $1 \%, 5 \%$, and $10 \%$ level, respectively. 
Table 11. Earnings plus Disability Income in the BOG versus NOG samples Dependent Variable: 100 x Ln(Earnings + DC Ben + SSDI Ben + SSI Ben), 1998-2006 only

\begin{tabular}{|c|c|c|c|c|c|}
\hline & $\begin{array}{l}\text { All } \\
(1) \\
\end{array}$ & $\begin{array}{c}\text { Nonwhites } \\
(2) \\
\end{array}$ & $\begin{array}{l}\text { Whites } \\
(3) \\
\end{array}$ & $\begin{array}{c}\text { AFQT }<45 \\
(4) \\
\end{array}$ & $\begin{array}{c}\text { AFQT } \geq 45 \\
(5)\end{array}$ \\
\hline \multicolumn{6}{|c|}{ A. Reduced Form Effect of Agent Orange Policy Change } \\
\hline BOG & $\begin{array}{l}-0.75 * * * \\
(0.17)\end{array}$ & $\begin{array}{l}-0.80 \\
(0.53)\end{array}$ & $\begin{array}{l}-0.70^{* * *} \\
(0.18)\end{array}$ & $\begin{array}{l}3.66^{* * *} \\
(0.28)\end{array}$ & $\begin{array}{l}-2.53 * * * \\
(0.23)\end{array}$ \\
\hline BOG * (YR-1998) & $\begin{array}{l}0.20 * * \\
(0.08)\end{array}$ & $\begin{array}{c}0.27 \\
(0.25)\end{array}$ & $\begin{array}{l}0.19 * * \\
(0.08)\end{array}$ & $\begin{array}{l}0.33^{* *} \\
(0.13)\end{array}$ & $\begin{array}{l}0.23^{* *} \\
(0.11)\end{array}$ \\
\hline $\begin{array}{l}\mathrm{BOG} *(\mathrm{YR}-2001) * \\
(\mathrm{YR} \geq 2002)\end{array}$ & $\begin{array}{l}0.51 * * * \\
(0.11)\end{array}$ & $\begin{array}{l}1.04 * * * \\
(0.36)\end{array}$ & $\begin{array}{l}0.45^{* * *} \\
(0.12)\end{array}$ & $\begin{array}{l}0.86^{* * * *} \\
(0.19)\end{array}$ & $\begin{array}{l}0.34 * * \\
(0.16)\end{array}$ \\
\hline Outcome Mean (1998) & $1,074.05$ & $1,043.42$ & $1,077.96$ & $1,048.71$ & $1,087.39$ \\
\hline Total Income Mean (1998) & 53,639 & 38,276 & 55,601 & 39,549 & 59,663 \\
\hline \# OBS (Cell)x(Year) & $2,137,665$ & 231,235 & $1,906,430$ & 658,480 & 988,152 \\
\hline \multicolumn{6}{|c|}{ B. 2SLS Estimates of DC Receipt on $100 \times$ Ln(Earnings + DC Ben + SSDI Ben + SSI Ben $)$} \\
\hline DC Enrollment & $\begin{array}{l}0.52^{* * *} \\
(0.12)\end{array}$ & $\begin{array}{l}0.83^{* * *} \\
(0.29)\end{array}$ & $\begin{array}{l}0.47 * * * \\
(0.13)\end{array}$ & $\begin{array}{l}0.73 * * * \\
(0.16)\end{array}$ & $\begin{array}{l}0.42^{* *} \\
(0.20)\end{array}$ \\
\hline Outcome Mean (1998) & $1,074.05$ & $1,043.42$ & $1,077.96$ & $1,048.71$ & $1,087.39$ \\
\hline Total Income Mean (1998) & 53,639 & 38,276 & 55,601 & 39,549 & 59,663 \\
\hline \# OBS (Cell)x(Year) & $2,137,665$ & 231,235 & $1,906,430$ & 658,480 & 988,152 \\
\hline
\end{tabular}

Notes: Panel A of this table reports estimates of equation (2) where the dependent variable is 100 times the log of each cell's mean annual earnings and total disability income. Panel B reports 2SLS estimates of the effects of DC receipt on the same outcome. The instrument in panel B is (BOG) $x(y e a r-2001) \times 1$ (year $\geq 2002)$ and the endogenous variable is the percentage of the cell enrolled in DC. Each cell has one observation for each year between 1998 and 2006, which are the years where DC information is available. Cells with 0 mean annual earnings are excluded. Earnings and disability income values are in \$2013. All regressions include year fixed effects and fixed effects for each combationation of (AFQT-quintile)x(year), (year of birth)x(year), and (race)x(year), where race is defined as white or nonwhite. Column 1 includes all veterans in our sample and columns 2-5 restrict the sample to veterans in the specified group. Columns 1-3 group veterans with a missing AFQT score into a sixth AFQT category while columns 4-5 exclude veterans with missing AFQT scores. All regressions weight each observation according to the number of veterans in the cell. Standard errors are reported in parentheses. ***, **, and $*$ denote significance at the $1 \%, 5 \%$, and $10 \%$ level, respectively. 


\section{Appendix Figure 1A. Data Diagram}

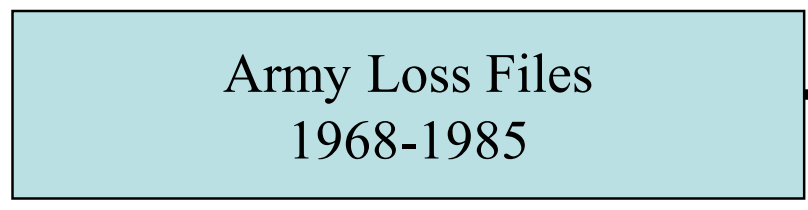

\section{Original OEMA Sample \\ $\mathrm{N}=4.086$ million}

\section{Department of Defense \\ Vietnam File}

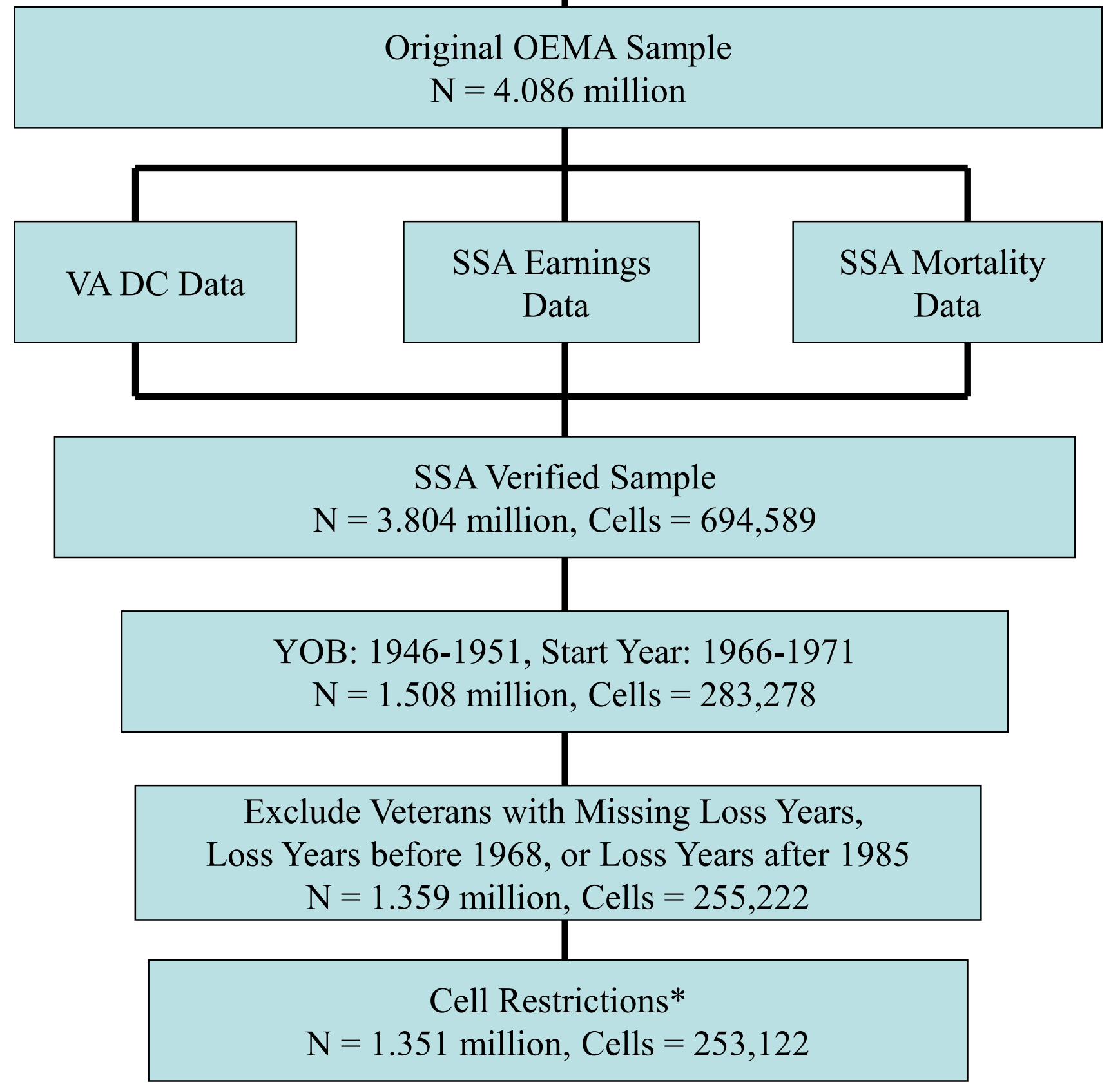

*Cell restrictions limit to the sample to cells where all veterans have the same birth year (466 observations dropped), all veterans have start years between 1966 and 1971 (2,677 observations dropped), all veterans have loss years between 1968 and 1985 (4,681 observations dropped), and no veterans have a missing loss year ( 80 observations dropped). 


\section{Appendix Figure 1B. Annual Observations Breakdown}

$$
\begin{gathered}
\text { Full Sample (One Year) } \\
\mathrm{N}=1.351 \text { million, Cells }=253,122
\end{gathered}
$$

$$
\begin{aligned}
& \mathrm{N}=1.351 \mathrm{mil} \mathrm{x} 12=16.212 \mathrm{mil} \\
& \text { Cells }=253,122 \times 12=3.037 \mathrm{mil}
\end{aligned}
$$

1996-2007 Panel after removing deceased Veterans**

$$
\begin{gathered}
\mathrm{N}=15.166 \mathrm{mil} \\
\text { Cells }=2.863 \mathrm{mil}
\end{gathered}
$$

**A deceased veteran is removed from the panel in the year of his death and all years following. If only a fraction of the cell is deceased in a particular year, all cell level averages are recomputed to reflect averages among living veterans only. 


\begin{tabular}{|c|c|c|c|c|c|c|c|c|}
\hline \multirow[b]{2}{*}{ CDR } & \multirow[b]{2}{*}{ Recipients } & \multirow[b]{2}{*}{$\begin{array}{c}\text { Payments (2013 } \\
\text { \$ Millions) }\end{array}$} & \multirow[b]{2}{*}{$\begin{array}{l}\text { Mean Annual } \\
\text { Benefit }\end{array}$} & \multirow[b]{2}{*}{ Gulf } & \multicolumn{3}{|c|}{ Share with Each Rating by Service Era } & \multirow[b]{2}{*}{ Peacetime } \\
\hline & & & & & Vietnam & Korea & WW II & \\
\hline $0 \%$ & 14,291 & $\$ 15$ & $\$ 1,030$ & $0.1 \%$ & $0.3 \%$ & $2.4 \%$ & $1.4 \%$ & $0.4 \%$ \\
\hline $10 \%$ & 775,346 & $\$ 1,212$ & $\$ 1,563$ & $27.3 \%$ & $21.8 \%$ & $30.6 \%$ & $33.0 \%$ & $37.3 \%$ \\
\hline $20 \%$ & 417,721 & $\$ 1,275$ & $\$ 3,052$ & $17.8 \%$ & $13.3 \%$ & $13.0 \%$ & $12.5 \%$ & $17.8 \%$ \\
\hline $30 \%$ & 334,931 & $\$ 1,742$ & $\$ 5,202$ & $15.3 \%$ & $10.6 \%$ & $12.4 \%$ & $13.1 \%$ & $11.0 \%$ \\
\hline $40 \%$ & 259,834 & $\$ 1,956$ & $\$ 7,530$ & $12.5 \%$ & $9.0 \%$ & $8.2 \%$ & $8.1 \%$ & $8.0 \%$ \\
\hline $50 \%$ & 161,568 & $\$ 1,709$ & $\$ 10,577$ & $7.2 \%$ & $5.9 \%$ & $5.4 \%$ & $5.8 \%$ & $4.7 \%$ \\
\hline $60 \%$ & 184,264 & $\$ 3,236$ & $\$ 17,564$ & $7.0 \%$ & $7.0 \%$ & $7.6 \%$ & $7.1 \%$ & $5.7 \%$ \\
\hline $70 \%$ & 165,257 & $\$ 4,263$ & $\$ 25,799$ & $4.8 \%$ & $8.5 \%$ & $5.5 \%$ & $5.4 \%$ & $4.2 \%$ \\
\hline $80 \%$ & 113,404 & $\$ 3,252$ & $\$ 28,678$ & $3.4 \%$ & $5.7 \%$ & $4.1 \%$ & $4.1 \%$ & $2.7 \%$ \\
\hline $90 \%$ & 60,546 & $\$ 1,896$ & $\$ 31,310$ & $1.7 \%$ & $3.1 \%$ & $2.3 \%$ & $2.3 \%$ & $1.4 \%$ \\
\hline $100 \%$ & 238,662 & $\$ 9,051$ & $\$ 37,926$ & $3.0 \%$ & $14.7 \%$ & $8.5 \%$ & $7.2 \%$ & $7.0 \%$ \\
\hline Total & $2,725,824$ & $\$ 29,608$ & $\$ 10,862$ & 694,813 & 947,598 & 159,804 & 328,044 & 595,565 \\
\hline
\end{tabular}

Source: U.S. Department of Veterans Affairs, 2006 Annual Benefits Report. Average annual benefit payments are in \$2013 (million 
Appendix Table 2. Distribution of Loss Year in OEMA Sample

\begin{tabular}{|c|c|c|c|c|}
\hline \multirow[b]{2}{*}{ Loss Year } & \multicolumn{2}{|c|}{ A. NOG Veterans } & \multicolumn{2}{|c|}{ B. BOG Veterans } \\
\hline & Observations & $\begin{array}{c}\text { Percent of NOG } \\
\text { Sample }\end{array}$ & Observations & $\begin{array}{c}\text { Percent of BOG } \\
\text { Sample }\end{array}$ \\
\hline 1960 & - & 0.00 & 1 & 0.00 \\
\hline 1961 & - & 0.00 & 2 & 0.00 \\
\hline 1962 & - & 0.00 & 2 & 0.00 \\
\hline 1963 & - & 0.00 & 2 & 0.00 \\
\hline 1964 & - & 0.00 & 8 & 0.00 \\
\hline 1965 & - & 0.00 & 25 & 0.00 \\
\hline 1966 & - & 0.00 & 140 & 0.01 \\
\hline 1967 & - & 0.00 & 250 & 0.02 \\
\hline 1968 & 17,787 & 0.69 & 7,128 & 0.48 \\
\hline 1969 & 83,222 & 3.21 & 165,959 & 11.14 \\
\hline 1970 & 265,968 & 10.25 & 258,909 & 17.37 \\
\hline 1971 & 241,772 & 9.32 & 273,725 & 18.37 \\
\hline 1972 & 122,400 & 4.72 & 219,993 & 14.76 \\
\hline 1973 & 164,026 & 6.32 & 77,013 & 5.17 \\
\hline 1974 & 175,414 & 6.76 & 51,296 & 3.44 \\
\hline 1975 & 162,983 & 6.28 & 32,696 & 2.19 \\
\hline 1976 & 160,387 & 6.18 & 26,037 & 1.75 \\
\hline 1977 & 146,516 & 5.65 & 23,410 & 1.57 \\
\hline 1978 & 129,296 & 4.98 & 21,334 & 1.43 \\
\hline 1979 & 141,220 & 5.44 & 19,612 & 1.32 \\
\hline 1980 & 137,754 & 5.31 & 15,946 & 1.07 \\
\hline 1981 & 119,916 & 4.62 & 12,921 & 0.87 \\
\hline 1982 & 128,458 & 4.95 & 12,153 & 0.82 \\
\hline 1983 & 141,806 & 5.46 & 11,393 & 0.76 \\
\hline 1984 & 131,090 & 5.05 & 11,597 & 0.78 \\
\hline 1985 & 125,179 & 4.82 & 10,857 & 0.73 \\
\hline 1986 & - & 0.00 & 6,052 & 0.41 \\
\hline 1987 & - & 0.00 & 5,089 & 0.34 \\
\hline 1988 & - & 0.00 & 5,684 & 0.38 \\
\hline 1989 & - & 0.00 & 5,212 & 0.35 \\
\hline 1990 & - & 0.00 & 4,392 & 0.29 \\
\hline 1991 & - & 0.00 & 3,501 & 0.23 \\
\hline 1992 & - & 0.00 & 3,671 & 0.25 \\
\hline 1993 & - & 0.00 & 2,563 & 0.17 \\
\hline Missing & - & 0.00 & 201,786 & 13.54 \\
\hline Total & $2,595,194$ & 100.00 & $1,490,359$ & 100.00 \\
\hline
\end{tabular}

Notes: This table reports the distribution of loss years within the NOG and BOG groups of the original OEMA sample. A loss year is the year a veteran exited the Army. 
Appendix Table 3. SSA Verification Rate by Start Year

\begin{tabular}{|c|c|c|c|c|}
\hline \multirow[b]{2}{*}{ Start Year } & \multicolumn{2}{|c|}{ A. NOG Veterans } & \multicolumn{2}{|c|}{ B. BOG Veterans } \\
\hline & Obs & $\begin{array}{l}\text { SSA Match } \\
\text { Rate }\end{array}$ & Obs & $\begin{array}{l}\text { SSA Match } \\
\text { Rate }\end{array}$ \\
\hline$\leq 1944$ & 6,970 & 86.5 & 8,209 & 95.8 \\
\hline 1945 & 1,321 & 85.3 & 2,808 & 96.4 \\
\hline 1946 & 2,057 & 88.2 & 3,943 & 97.2 \\
\hline 1947 & 2,027 & 87.3 & 3,754 & 96.4 \\
\hline 1948 & 3,752 & 87.8 & 5,988 & 96.3 \\
\hline 1949 & 3,846 & 88.6 & 4,794 & 95.8 \\
\hline 1950 & 5,400 & 82.2 & 8,286 & 95.0 \\
\hline 1951 & 4,275 & 82.4 & 13,569 & 95.3 \\
\hline 1952 & 1,925 & 82.8 & 13,125 & 98.0 \\
\hline 1953 & 1,983 & 81.5 & 15,593 & 98.6 \\
\hline 1954 & 1,522 & 82.4 & 13,370 & 98.9 \\
\hline 1955 & 1,807 & 84.3 & 12,950 & 99.0 \\
\hline 1956 & 1,776 & 84.8 & 12,132 & 98.8 \\
\hline 1957 & 1,779 & 88.1 & 12,107 & 99.0 \\
\hline 1958 & 2,485 & 88.4 & 15,181 & 98.9 \\
\hline 1959 & 2,254 & 91.0 & 14,769 & 98.9 \\
\hline 1960 & 2,339 & 93.5 & 14,192 & 99.0 \\
\hline 1961 & 4,018 & 93.6 & 16,002 & 98.8 \\
\hline 1962 & 4,359 & 91.4 & 15,689 & 98.5 \\
\hline 1963 & 4,778 & 91.4 & 15,895 & 98.4 \\
\hline 1964 & 6,362 & 91.5 & 18,357 & 98.5 \\
\hline 1965 & 9,675 & 91.6 & 26,859 & 98.2 \\
\hline 1966 & 38,014 & 94.4 & 88,681 & 98.8 \\
\hline 1967 & 96,939 & 93.3 & 174,641 & 97.2 \\
\hline 1968 & 196,281 & 92.3 & 263,378 & 95.5 \\
\hline 1969 & 199,973 & 87.0 & 263,700 & 93.1 \\
\hline 1970 & 163,525 & 87.1 & 149,738 & 98.8 \\
\hline 1971 & 191,736 & 86.6 & 60,564 & 99.4 \\
\hline 1972 & 215,043 & 86.2 & 15,087 & 99.5 \\
\hline 1973 & 144,792 & 85.6 & 3,053 & 98.8 \\
\hline 1974 & 187,413 & 85.8 & 1,753 & 99.1 \\
\hline 1975 & 162,643 & 88.2 & 1,802 & 98.6 \\
\hline$\geq 1976$ & 920,849 & 96.3 & 3,624 & 99.1 \\
\hline Missing & 1,276 & 81.7 & 196,766 & 99.4 \\
\hline Total & $2,595,194$ & 90.9 & $1,490,359$ & 97.0 \\
\hline
\end{tabular}

Notes: This table reports SSA verification rates for veterans by start year and BOG or NOG status. 


\begin{tabular}{|c|c|c|c|c|c|c|}
\hline & \multicolumn{3}{|c|}{ A. Army/SSA Verified Sample (1999) } & \multicolumn{3}{|c|}{ B. Vietnam Veterans born 1946-1951: 2000 Census } \\
\hline & $\begin{array}{l}\text { All } \\
(1) \\
\end{array}$ & $\begin{array}{c}\text { Whites } \\
(2) \\
\end{array}$ & $\begin{array}{c}\text { Nonwhites } \\
(3) \\
\end{array}$ & $\begin{array}{l}\text { All } \\
(1) \\
\end{array}$ & $\begin{array}{c}\text { Whites } \\
(2)\end{array}$ & $\begin{array}{c}\text { Nonwhites } \\
\text { (3) } \\
\end{array}$ \\
\hline Age in 1999 & $\begin{array}{l}50.5 \\
(1.5)\end{array}$ & $\begin{array}{l}50.5 \\
(1.5)\end{array}$ & $\begin{array}{l}50.3 \\
(1.5)\end{array}$ & $\begin{array}{l}50.7 \\
(1.6)\end{array}$ & $\begin{array}{l}50.7 \\
(1.6)\end{array}$ & $\begin{array}{l}50.5 \\
(1.6)\end{array}$ \\
\hline \multicolumn{7}{|l|}{ Race } \\
\hline White & 88.7 & 100.0 & 0.0 & 86.7 & 100.0 & 0.0 \\
\hline Nonwhite & 11.3 & 0.0 & 100.0 & 13.3 & 0.0 & 100.0 \\
\hline \multicolumn{7}{|l|}{ Education } \\
\hline HS Dropout & 27.3 & 26.9 & 30.7 & 5.2 & 4.7 & 8.3 \\
\hline HS Grad & 43.6 & 42.9 & 49.2 & 39.3 & 39.1 & 41.0 \\
\hline Some College & 14.7 & 15.3 & 10.4 & 29.7 & 29.1 & 33.4 \\
\hline College Grad & 6.9 & 7.5 & 2.4 & 15.9 & 16.6 & 11.3 \\
\hline More than College & 0.4 & 0.5 & 0.1 & 9.9 & 10.5 & 6.0 \\
\hline Positive Earnings & 84.1 & 85.0 & 76.5 & 82.2 & 83.1 & 76.3 \\
\hline \multicolumn{7}{|c|}{ Annual Earnings (\$2013) } \\
\hline Mean & $\begin{array}{c}52,512 \\
(76,853)\end{array}$ & $\begin{array}{c}54,570 \\
(80,899)\end{array}$ & $\begin{array}{c}36,376 \\
(24,652)\end{array}$ & $\begin{array}{c}58,488 \\
(65,224)\end{array}$ & $\begin{array}{c}60,909 \\
(67,114)\end{array}$ & $\begin{array}{c}42,703 \\
(48,337)\end{array}$ \\
\hline Mean (if >0) & $\begin{array}{c}61,053 \\
(80,366)\end{array}$ & $\begin{array}{c}62,898 \\
(84,600)\end{array}$ & $\begin{array}{c}46,566 \\
(27,209)\end{array}$ & $\begin{array}{c}71,158 \\
(65,378)\end{array}$ & $\begin{array}{c}73,303 \\
(67,174)\end{array}$ & $\begin{array}{c}55,935 \\
(48,170)\end{array}$ \\
\hline Median & 45,530 & 47,123 & 33,879 & 48,941 & 49,220 & 36,356 \\
\hline Observations & $1,286,921$ & $1,141,340$ & 145,581 & 203,781 & 178,601 & 25,180 \\
\hline
\end{tabular}

Notes: This table reports summary statistics for veterans in the SSA verified sample and veterans in the 2000 census. Panel A maintains the same sample restrictions described in the data appendix and further restricts to veterans who were still alive as of 1999. All statistics in panel A are from 1999. Panel B reports summay statistics for veterans in the 5 percent 2000 Census IPUMS extract who were born between 1946 and 1951 . All earnings are in \$2013. 
Appendix Table 5. DC Progression and LFP for Pre-Existing Beneficiaries and New Beneficiaries

\begin{tabular}{|c|c|c|c|c|c|c|}
\hline & \multicolumn{3}{|c|}{ A. CDR (Individual Level) } & \multicolumn{3}{|c|}{ B. LFP (Cell Level) } \\
\hline & All Veterans & $\begin{array}{l}\text { Enrolled in } \\
\text { DC by } 1998\end{array}$ & $\begin{array}{c}\text { Not Enrolled } \\
\text { in DC by } \\
1998\end{array}$ & All Veterans & $\begin{array}{c}\text { High DC_98 } \\
\text { Cell }\end{array}$ & $\begin{array}{c}\text { Low DC_98 } \\
\text { Cell }\end{array}$ \\
\hline & $(1)$ & $(2)$ & $(3)$ & $(1)$ & $(2)$ & (3) \\
\hline BOG & $\begin{array}{l}2.87 * * * \\
(0.03)\end{array}$ & $\begin{array}{l}2.55^{* * * *} \\
(0.18)\end{array}$ & $\begin{array}{l}-0.01 \\
(0.02)\end{array}$ & $\begin{array}{l}-0.66^{* * *} \\
(0.06)\end{array}$ & $\begin{array}{l}-0.71 * * * \\
(0.27)\end{array}$ & $\begin{array}{l}0.21^{* * *} \\
(0.07)\end{array}$ \\
\hline BOG * (YR-1998) & $\begin{array}{l}0.34 * * * \\
(0.01)\end{array}$ & $\begin{array}{l}0.84 * * * \\
(0.08)\end{array}$ & $\begin{array}{l}0.22 * * * \\
(0.01)\end{array}$ & $\begin{array}{l}-0.15^{* * *} \\
(0.03)\end{array}$ & $\begin{array}{l}-0.35^{* * *} \\
(0.13)\end{array}$ & $\begin{array}{l}-0.11^{* * *} \\
(0.03)\end{array}$ \\
\hline $\begin{array}{l}\mathrm{BOG} *(\mathrm{YR}-2001) * \\
(\mathrm{YR} \geq 2002)\end{array}$ & $\begin{array}{l}0.66^{* * * *} \\
(0.02)\end{array}$ & $\begin{array}{l}0.26^{* *} \\
(0.12)\end{array}$ & $\begin{array}{l}0.73 * * * \\
(0.01)\end{array}$ & $\begin{array}{l}-0.18^{* * *} \\
(0.04)\end{array}$ & $\begin{array}{c}0.06 \\
(0.17)\end{array}$ & $\begin{array}{l}-0.21^{* * *} \\
(0.04)\end{array}$ \\
\hline $\begin{array}{l}\text { Outcome Mean (1998) } \\
\text { \# OBS } \\
\text { Years }\end{array}$ & $\begin{array}{c}3.96 \\
11,376,787 \\
1998-2006\end{array}$ & $\begin{array}{c}38.21 \\
1,165,699 \\
1998-2006\end{array}$ & $\begin{array}{c}0.00 \\
10,211,088 \\
1998-2006\end{array}$ & $\begin{array}{c}84.68 \\
2,372,076 \\
1998-2007\end{array}$ & $\begin{array}{c}77.23 \\
244,709 \\
1998-2007\end{array}$ & $\begin{array}{c}85.58 \\
2,127,367 \\
1998-2007\end{array}$ \\
\hline
\end{tabular}

Notes: This table reports estimates of equation (2) where the dependent variable is a veteran's Combined Disability Rating (panel A), or the percentage of the veteran's cell with positive annual earnings (panel B). In panel A, column 1 includes all veterans in the sample, column 2 only includes veterans who initially enrolled in DC in 1998 or earlier, and column 3 only includes vetearns who were not enrolled in DC as of 1998. Veterans with an IU award are given a CDR of 100. In panel B, column 1 includes all cells, column 2 only includes cells where at least one third of veterans in the cell were enrolled in DC as of 1998, and column 3 includes cells where fewer than one third of veterans in the cell were enrolled in DC as of 1998. All regressions in panel A are at the individual level while regressions in panel $\mathrm{B}$ are at the cell level and are weighted by the number of veterans in a cell in a particular year. All regressions include year fixed effects and fixed effects for each combationation of (AFQT-quintile)x(year), (year of birth)x(year), and (race)x(year), where race is defined as white or nonwhite and veterans with a missing AFQT score are grouped into a sixth AFQT category. Standard errors are reported in parentheses. ${ }^{* * *}, * *$, and $*$ denote significance at the $1 \%, 5 \%$, and $10 \%$ level, respectively. 